University of Tennessee College of Law

Legal Scholarship Repository: A Service of the Joel A. Katz Law Library

3-19-2018

\title{
Should We Be Concerned About Data-opolies?
}

Maurice Stucke

University of Tennessee College of Law

Follow this and additional works at: https://ir.law.utk.edu/utklaw_facpubs

\section{Recommended Citation}

Stucke, Maurice, "Should We Be Concerned About Data-opolies?" (2018). UTK Law Faculty Publications. 130.

https://ir.law.utk.edu/utklaw_facpubs/130

This Article is brought to you for free and open access by the Faculty Work at Legal Scholarship Repository: A Service of the Joel A. Katz Law Library. It has been accepted for inclusion in UTK Law Faculty Publications by an authorized administrator of Legal Scholarship Repository: A Service of the Joel A. Katz Law Library. For more information, please contact eliza.boles@utk.edu. 


\title{
Should We Be Concerned ABOut Data- OPOLIES?
}

\author{
Maurice E. Stucke*
}

Cite As: 2 Geo. L. Tech. Rev. 275 (2018)

\section{INTRODUCTION}

As we transition to a data-driven economy, we are witnessing the emergence of data-opolies - companies that control a key platform, which, like a coral reef, attracts users, sellers, advertisers, software developers, apps, and accessory makers to its ecosystem. Apple and Google, for example, each control a popular mobile phone operating system (and key apps on that platform); Amazon controls the largest online merchant platform; and Facebook controls the largest social network platform. Through their leading platforms, a significant volume and variety of personal data flows. The velocity in acquiring and exploiting this personal data helps these companies obtain significant market power. ${ }^{1}$

The European competition authorities have begun to recognize this and have brought actions against four data-opolies: Google, Apple, Facebook, and Amazon (or GAFA for short). (The Economist created its own acronym, BAADD, "too big, anti-competitive, addictive and destructive to democracy.",

The European Commission recently fined Google a record $€ 2.42$ billion for leveraging its monopoly in search to comparative shopping. ${ }^{3}$ The Commission also preliminarily found Google to have abused its

\footnotetext{
* Professor, University of Tennessee College of Law; co-founder, The Konkurrenz Group. The author would like to thank the participants of Georgetown Law's Institute for Technology Law \& Policy's Symposium, The Governance \& Regulation of Information Platforms, for their helpful comments and the University of Tennessee College of Law for the summer research grant.

${ }^{1}$ Maurice E. Stucke \& Allen P. Grunes, Big Data And Competition Policy (2016); Ariel Ezrachi \& Maurice E. Stucke, Virtual Competition: The Promise and PERILS OF THE ALGORITHM-DRIVEN ECONOMY (2016).

${ }^{2}$ Evan Smith, The Techlash Against Amazon, Facebook, and Google-and What They Can Do, ECONOMIST (Jan. 20, https://www.economist.com/briefing/2018/01/20/the-techlash-against-amazon-facebookand-google-and-what-they-can-do.

3 Case AT.39740, Google Search (Shopping), 2017 E.C. 1/2003, http://ec.europa.eu/competition/antitrust/cases/dec_docs/39740/39740_14996_3.pdf

[https://perma.cc/JGM8-49QC].
} 
dominant position with its Android mobile operating system ("by imposing restrictions on Android device manufacturers and mobile network operators"4) and AdSense (by "preventing third-party websites from sourcing search ads from Google's competitors"). Moreover, Google is under investigation for other possibly anticompetitive practices. ${ }^{6}$

Facebook abused its dominant position, Germany's competition agency preliminarily found, "by making the use of its social network conditional on its being allowed to limitlessly amass every kind of data generated by using third-party websites and merge it with the user's Facebook account." 7 The European Commission fined Facebook $€ 110$ million for "providing incorrect or misleading information during the Commission's 2014 investigation under the EU Merger Regulation of Facebook's acquisition of WhatsApp."

Apple violated the European Union state aid rules when Ireland granted it undue tax benefits of up to $€ 13$ billion. This was not a monopolization case. Instead, when Apple was allowed "to pay substantially less tax than other businesses," the result was distorted competition. ${ }^{9}$ Ireland had to recover the illegal aid. The Commission in 2018 was also investigating Apple's proposed acquisition of Shazam, where concerns over personal data could play a role. ${ }^{10}$

4 European Commission Press Release IP/16/1492, Antitrust: Commission Sends Statement of Objections to Google on Android Operating System and Applications (Apr. 20, 2016), http://europa.eu/rapid/press-release_IP-16-1492_en.htm [https://perma.cc/S7D5-EGXY].

${ }^{5}$ European Commission Press Release IP/17/1784, Antitrust: Commission Fines Google $€ 2.42$ Billion for Abusing Dominance as Search Engine by Giving Illegal Advantage to Own Comparison Shopping Service (June 27, 2017), http://europa.eu/rapid/pressrelease_IP-17-1784_en.htm [https://perma.cc/6DTG-W9S6].

${ }^{6}$ Id. See also Älphabet, Inc., Annual Report (Form 10-K) (Dec. 31, 2017), https://abc.xyz/investor/pdf/20171231_alphabet_10K.pdf [https://perma.cc/CVQ7THK5] (Argentina's, India's, Brazil's and Korea's competition authorities are also investigating Google's business practices).

${ }^{7}$ Bundeskartellamt Press Release, Preliminary Assessment in Facebook Proceeding: Facebook's Collection and Use of Data from Third-Party Sources Is Abusive (Dec. 19, 2017),

http://www.bundeskartellamt.de/SharedDocs/Meldung/EN/Pressemitteilungen/2017/19_1 2_2017_Facebook.html [https://perma.cc/PD8R-LFLC].

${ }^{8}$ European Commission Press Release IP/17/1369, Mergers: Commission Fines Facebook $€ 110$ million for Providing Misleading Information about WhatsApp Takeover (May 18, 2017), http://europa.eu/rapid/press-release_IP-17-1369_en.htm [https://perma.cc/CC42-VHCJ].

9 European Commission Press Release IP/16/2923, State Aid: Ireland Gave Illegal Tax Benefits to Apple Worth up to $€ 13$ Billion (Aug. 30, 2016), http://europa.eu/rapid/pressrelease_IP-16-2923_en.htm [https://perma.cc/GM7M-3BJZ].

${ }^{10}$ The concern is that "following the takeover of Shazam, Apple would obtain access to commercially sensitive data about customers of its competitors for the provision of music 
Finally, the Commission targeted Amazon's anticompetitive mostfavored nation clause. ${ }^{11}$ It also found that Luxembourg gave Amazon illegal tax benefits worth around $€ 250$ million. ${ }^{12}$

While we will likely see more fines and behavioral (or structural) remedies in the next few years from the Europeans, the data-opolies largely escaped antitrust scrutiny under the Obama and Bush administrations. The U.S. Department of Justice (DOJ) prosecuted Apple and Google for per se illegal offenses. ${ }^{13}$ The Federal Trade Commission

streaming services .... Access to such data could allow Apple to directly target its competitors' customers and encourage them to switch to Apple Music. As a result, competing music streaming services could be put at a competitive disadvantage." European Commission Press Release IP/18/3505, Mergers: Commission opens in-depth investigation into Apple's proposed acquisition of Shazam (Apr. 23, 2018), http://europa.eu/rapid/press-release_IP-18-3505_en.htm [https://perma.cc/PX2Y-2UBN]; see also Thibault Larger \& Simon Van Dorpe, Politico Fair Play: Tempted by the Apple - Vestager, the Muse - Paranoid Android, Politico (June 11, 2018), https://www.politico.eu/article/politico-fair-play-tempted-by-the-apple-vestager-themuse-paranoid-android/ [https://perma.cc/53GT-6HFZ].

${ }^{11}$ A simple version of a most-favored-nation clause is when a retailer pledges to match a rival's discount. While it may appear pro-competitive, MFNs, at times, can lessen competition. The Commission alleged that Amazon's MFN:

required publishers to offer Amazon similar (or better) terms and conditions as those offered to its competitors and/or to inform Amazon about more favourable or alternative terms given to Amazon's competitors. The clauses covered not only price but many aspects that a competitor can use to differentiate itself from Amazon, such as an alternative business (distribution) model, an innovative e-book or a promotion.

The Commission considered that such clauses could make it more difficult for other e-book platforms to compete with Amazon by reducing publishers' and competitors' ability and incentives to develop new and innovative e-books and alternative distribution services. The clauses may have led to less choice, less innovation and higher prices for consumers due to less overall competition in the European Economic Area (EEA) in e-book distribution.

European Commission Press Release IP/17/1223, Antitrust: Commission accepts commitments from Amazon on e-books (May 4, 2017), http://europa.eu/rapid/pressrelease_IP-17-1223_en.htm [https://perma.cc/S8EN-PC6Q].

12 European Commission Press Release IP/17/3701, State Aid: Commission Finds Luxemburg Gave Illegal Tax Benefits to Amazon Worth Around €250 Million (Oct. 4, 2017), http://europa.eu/rapid/press-release_IP-17-3701_en.htm [https://perma.cc/A2NDW4XM].

${ }^{13}$ See United States v. Apple, Inc., 791 F.3d 290, 297 (2d Cir. 2015) (prosecuting Apple and several large book publishers for conspiring to raise the price of eBooks, particularly new releases and New York Times bestsellers, where the intended target was Amazon); 
(FTC) also challenged Google's and Facebook's privacy violations under Section 5 of the FTC Act. ${ }^{14}$ Notably, while the European Commission found Google's search bias to be anticompetitive, the FTC did not. It argued that "[c]hallenging Google's product design decisions in this case would require the Commission - or a court - to second-guess a firm's product design decisions where plausible procompetitive justifications have been offered, and where those justifications are supported by ample evidence." 15

The head of the DOJ's Antitrust Division noted the enforcement gap between the United States and Europe: "European competition law still imposes a 'special duty' on dominant market players, while we in the U.S. do not believe any such duty exists." ${ }^{\prime \prime} \mathrm{He}$ also noted that the DOJ has "particular concerns in digital markets,"17 but absent "demonstrable harm to competition and consumers, we are reluctant to impose special duties on digital platforms, out of our concern that special duties might stifle the very innovation that has created dynamic competition for the benefit of consumers." 18

United States v. Adobe Systems, Inc., Civ. No. 1:10-cv-01629, 2011 WL U.S. Dist. LEXIS 83756 (D.D.C. Mar. 17, 2011), https://www.justice.gov/atr/case-document/finaljudgment-0 [https://perma.cc/TT6Q-NHUU] (entering into civil consent decrees with Apple, Google, and four other technology firms that prohibited them from entering into agreements restraining employee recruitment).

${ }^{14}$ See, e.g., Google, Inc., FTC File No. 102-3136, Dkt. No. C-4336 (Oct. 13, 2011) (decision and order); Facebook, Inc., FTC File No. 092-3184, Dkt. No. C-4365 (July 27, 2012) (decision and order).

15 Statement of the U.S. Federal Trade Commission Regarding Google's Search Practices, In the Matter of Google, Inc., FTC File No. 111-0163 (Jan. 3, 2013), https:/www.ftc.gov/system/files/documents/public_statements/295971/130103googlesea rchstmtofcomm.pdf [https://perma.cc/6F87-WZ5E] [hereinafter FTC Google Statement].

${ }^{16}$ Makan Delrahim, Assistant Attorney Gen., Dep't of Justice, Good Times, Bad Times, Trust Will Take Us Far: Competition Enforcement and the Relationship Between Washington and Brussels (Feb. 21, 2018), https://www.justice.gov/opa/speech/assistantattorney-general-makan-delrahim-delivers-remarks-college-europe-brussels

[https://perma.cc/K38A-PYE2]. Contrary to the AAG's assertion, the common law has imposed special duties on monopolies. See, e.g., Munn v. People of State of Illinois, 94 U.S. 113, 127-28 (1876) ("There is no doubt that the general principle is favored, both in law and justice, that every man may fix what price he pleases upon his own property, or the use of it; but if for a particular purpose the public have a right to resort to his premises and make use of them, and he have a monopoly in them for that purpose, if he will take the benefit of that monopoly, he must, as an equivalent, perform the duty attached to it on reasonable terms.") (internal citation omitted). Moreover, monopolies, unlike other firms, still have at times a duty to deal. See, e.g., Otter Tail Power Co. v. United States, 410 U.S. 366, 373 (1973) (monopoly's consistent refusals to wholesale or wheel power to its municipal customers constituted illegal monopolization).

${ }^{17}$ Delrahim, supra note 16.

${ }^{18} I d$. 
With the divergence in antitrust enforcement, some claim bias and protectionism. ${ }^{19}$ Others argue that it is impossible to find any way in which consumers are being harmed when the services are free and constantly evolving. ${ }^{20}$ Given the European and U.S. divergence over dataopolies, Part I explores one possible factor: data-opolies, under antitrust's consumer welfare standard, are seemingly benign. Data-opolies might have power upstream. Google and Facebook, for example, could conceivably dominate certain online advertising markets; Amazon could exert significant buyer power (for books and other products). ${ }^{21}$ But Amazon, while striking fear in many retail sectors and among suppliers, is generally viewed as offering consumers an array of low-cost products and services. Most of Google's and Facebook's services for consumers are ostensibly "free." 22 Consequently, Robert Bork argued that there "is no coherent case for monopolization because a search engine, like Google, is free to consumers and they can switch to an alternative search engine with a click." 23

19 James Titcomb, Google Launches Fightback against Record £2.2bn Brussels Fine, TELEGRAPH (Sept. 9, 2017), https://www.telegraph.co.uk/technology/2017/09/09/googlelaunches-fightback-against-record-22bn-brussels-fine/ [https://perma.cc/45H6-KR89]; Foo Yun Chee, EU Antitrust Regulators Open Third Front Against Google, ReUTERS Australian AND NeW ZEALAND Bus. News (July 14, 2016), https://www.reuters.com/article/us-eu-google-antitrust-idUSKCN0ZU0YS

[https://perma.cc/9F6W-W397].

${ }^{20}$ Adam Thierer, Can There Be a Market for Unpaid Search Results and Could Google Be Classified as a Public Utility?, LAw Professor Blogs Network (May 21, 2012), http://www.typepad.com/services/trackback/6a00d8341bfae553ef016305aeec92970d [https://perma.cc/R5FL-UDTS]; see generally Nathan Newman, The Costs of Lost Privacy: Consumer Harm and Rising Economic Inequality in the Age of Google, $40 \mathrm{WM}$. Mitchell L. REV. 849, 850 (2014) (noting that the "lack of analysis of the consumer harm from loss of data privacy is one reason Google, despite its clear dominance of search advertising, has escaped antitrust prosecution so far in the United States" and "Google's defenders often deny that consumers lose anything from their interaction with Google").

${ }^{21}$ Evan Smith, supra note 2 ("Facebook and Google are responsible for nearly $80 \%$ of news publishers' referral traffic. In 2017 they claimed around $80 \%$ of every new onlinead dollar in America. Google dominates as much as $85 \%$ of online-search-ad revenue worldwide. When you combine the stuff Amazon sells itself with the stuff others sell using it as a marketplace, the company controls approximately $40 \%$ of America's online commerce.").

${ }^{22}$ Competition and Technology: Taming the Titans, ECONOMIST (Jan. 20, 2018), https://www.economist.com/leaders/2018/01/18/how-to-tame-the-tech-titans

[https://perma.cc/PQ88-PWPC] ("America's trustbusters have given tech giants the benefit of the doubt. They look for consumer harm, which is hard to establish when prices are falling and services are 'free."').

Robert Bork, Antitrust and Google, CHI. TRIB. (Apr. 6, 2012), http://articles.chicagotribune.com/2012-04-06/opinion/ct-perspec-0405-bork- 
Data-opolies, unlike earlier monopolies, have not exercised their power by charging consumers higher prices. But this does not mean dataopolies are harmless. Digging deeper, Part II provides a taxonomy of potential harms by data-opolies. Among these potential harms are less privacy protection; less innovation and dynamic disruption in markets in which they dominate; and political, moral, and social concerns. Part III discusses why data-opolies may be more durable than some earlier monopolies.

The goal is not to vilify data-opolies. Not every dominant tech platform will have the incentive and ability to cause harm. Instead, one must understand the scope of harm data-opolies present, absent vigilant antitrust enforcement. This is critical because the DOJ has only brought one monopolization case under section 2 of the Sherman Act from 2000 onward. ${ }^{24}$ In contrast, between 1970 and 1972, the DOJ brought thirtynine civil and three criminal cases against monopolies and oligopolies. ${ }^{25}$ This abdication is not justifiable going forward, given the risks that dataopolies pose not only to our wallets but also to our privacy, autonomy, democracy, and well-being.

\section{Data-opolies Through A Price Lens}

The offense of monopolization under section 2 of the Sherman $\mathrm{Act}^{26}$ has two elements: "(1) the possession of monopoly power in the relevant market and (2) the willful acquisition or maintenance of that power as distinguished from growth or development as a consequence of a superior product, business acumen, or historic accident." ${ }^{27}$ Absent a merger to monopoly, ${ }^{28}$ a monopoly in itself is not per se illegal. In a thoughtful opinion, Judge Wyzanski outlined what a plaintiff must show:

20120406_1_unpaid-search-results-search-engines-search-algorithms

[https://perma.cc/N6VP-CJES].

${ }^{24}$ U.S. DeP'T OF Justice, Antitrust Division: WorkloAd Statistics 2007-2016 (2017), https://www.justice.gov/atr/file/788426/download [https://perma.cc/E5LKX6R8]; U.S. DeP'T OF Justice, Antitrust Division: Workload Statistics 20002009 (2012), https://www.justice.gov/sites/default/files/atr/legacy/2012/04/04/281484.pdf [https://perma.cc/6ZAE-CQ4J].

${ }^{25}$ U.S. DeP'T of Justice, Antitrust Division: Workload Statistics 1970-1979 (June 25, 2015), https://www.justice.gov/atr/antitrust-division-workload-statistics-fy1970-1979 [https://perma.cc/F7PP-5EDW].

${ }^{26}$ Section 2 of the Sherman Act, 15 U.S.C. $\S 2$, makes it unlawful for any person to "monopolize, or attempt to monopolize, or combine or conspire with any other person or persons, to monopolize any part of the trade or commerce among the several States, or with foreign nations ...."

${ }^{27}$ United States v. Grinnell Corp., 384 U.S. 563, 570-71 (1966).

${ }^{28}$ Section 7 of the Clayton Act, 15 U.S.C. $§ 18$. 
(1) "defendant has, and exercises, such overwhelming strength in the [relevant] market that it controls that market, (2) this strength excludes some potential, and limits some actual, competition, and (3) this strength is not attributable solely to defendant's ability, economies of scale, research, natural advantages, and adaptation to inevitable economic laws. ${ }^{, 29}$ Thus, to survive a motion to dismiss, antitrust plaintiffs, including the United States, must allege the willful conduct's "actual or potential harm to competition." 30 Typically the behavior is characterized as exclusionary or predatory.

Ordinarily when a company illegally attains or maintains its monopoly, one anticompetitive effect is the monopoly itself, such as less output, higher prices, or reduced quality. ${ }^{31}$ Under neoclassical economic theory, another harm from a monopolist in a market with a downwardsloping demand curve is the deadweight loss. Here, the monopolist reduces output below competitive levels and extracts a supra-competitive price from its remaining customers. Absent perfect price discrimination, some buyers forego or reduce their purchases at the supra-competitive price, and this reduction represents the deadweight welfare loss. A third harm is the cost of the monopoly's wasteful rent-seeking activity. ${ }^{32}$

Data-opolies are unlikely to raise prices for their goods and services. No one alleged that Facebook, in acquiring WhatsApp or Instagram, would start charging users a fee. Instead, Facebook eliminated WhatsApp's small fee in some countries for its texting app. ${ }^{33}$ The presumption is that "lower prices improve consumer welfare (all else being equal)." ${ }^{\text {34 }}$ Since data-opolies are not raising prices above competitive levels (or reducing output below competitive levels), some may question if they even possess monopoly power.

Quality can also increase, primarily from network effects. "Network effects occur when the value of a product or service for a customer increases when the number of other customers also using it

${ }^{29}$ United States v. United Shoe Mach. Corp., 110 F. Supp. 295, 343 (D. Mass. 1953), aff'd, 347 U.S. 521 (1954).

${ }^{30}$ Jacobs v. Tempur-Pedic Int'l, Inc., 626 F.3d 1327, 1339 (11th Cir. 2010).

${ }^{31}$ See Duty Free Americas, Inc. v. Estee Lauder Co., Inc., 797 F.3d 1248, 1263 (11th Cir. 2015).

${ }^{32}$ Richard A. Posner, The Social Costs of Monopoly and Regulation, 83 J. PoL. ECON. 807, 809-15 (1975).

33 Ina Fried, Facebook's WhatsApp is Now Free, RECODE (Jan. 18, 2016), https://www.recode.net/2016/1/18/11588896/facebook-owned-whatsapp-to-dropsubscription-fees-for-its-popular [https://perma.cc/67F2-59D6].

${ }^{34}$ United States v. Apple, Inc., 791 F.3d 290, 332 (2d Cir. 2015) (The antitrust concern with below-cost (i.e., predatory) pricing occurs "only if there is a 'dangerous probability" that the firm engaging in it will later recoup its losses by raising prices to monopoly levels after driving its rivals out of the market."). 
increases. ${ }^{\prime 35}$ Telephones are a classic example. As more people purchase telephones, more people become available to call. In turn, having more people to call increases the value of owning a telephone. Facebook's social network illustrates these network effects. ${ }^{36}$

One indirect network effect is the positive feedback loop in attracting manufacturers and developers. ${ }^{37}$ Digital personal assistants, like Alexa and Google Home, are one example of such a feedback loop. It is inefficient for developers to create apps, hardware, and software for every digital assistant. Instead, developers likely focus on the top-selling digital assistants. $^{38}$ So, if more people primarily use Amazon's Alexa, its platform will likely attract more developers and smart appliance manufacturers. Consequently, Alexa will learn more skills relative to

${ }^{35}$ Case M.8124, Microsoft / LinkedIn, 2016 E.C. 139/2004 I 341 (Dec. 6, 2016), http://ec.europa.eu/competition/mergers/cases/decisions/m8124_1349_5.pdf

[https://perma.cc/W2TP-BHDE] [hereinafter Microsoft/LinkedIn Decision]; see also United States v. Microsoft, 253 F.3d 34, 49 (D.C. Cir. 2001).

${ }^{36}$ Bundeskartellamt Press Release: Preliminary Assessment in Facebook Proceeding: Facebook's Collection and Use of Data from Third-Party Sources Is Abusive (Dec. 19, 2017),

https://www.bundeskartellamt.de/SharedDocs/Meldung/EN/Pressemitteilungen/2017/19 12_2017_Facebook.html [https://perma.cc/WXG9-N56P]; see also Bundeskartellamt, Background Information on the Facebook Proceeding (Dec. 19, 2017), http://www.bundeskartellamt.de/SharedDocs/Publikation/EN/Diskussions_Hintergrundpa piere/2017/Hintergrundpapier_Facebook.pdf [https://perma.cc/CX7X-RN4P].

${ }^{37}$ Indirect network effects arise when people increasingly use a product or technology (i.e., software platforms). The more people that use the platform, "the more there will be invested in developing products compatible with that platform, which, in turn reinforces the popularity of that platform with users." Case T-201/04, Microsoft Corp. v. Comm'n, 2007 E.C.R. II-3601, $₫ 1061$.

${ }^{38}$ United States v. Microsoft Corp., 84 F. Supp. 2d 9, 20 (D.D.C. 1999):

The fixed costs of producing software, including applications, is very high. By contrast, marginal costs are very low. Moreover, the costs of developing software are "sunk"-once expended to develop software, resources so devoted cannot be used for another purpose. The result of economies of scale and sunk costs is that application developers seek to sell as many copies of their applications as possible. An application that is written for one PC operating system will operate on another PC operating system only if it is ported to that system, and porting applications is both time-consuming and expensive. Therefore, application developers tend to write first to the operating system with the most users-Windows. Developers might then port their applications to other operating systems, but only to the extent that the marginal added sales justify the cost of porting. In order to recover that cost, [independent software vendors] that do go to the effort of porting frequently set the price of ported applications considerably higher than that of the original versions written for Windows. 
competitors, increasing its appeal to prospective purchasers and, in turn, to developers and manufacturers.

Another data-driven network effect is learning-by-doing, exemplified by search engines. The more people who use a particular search engine, the more likely the search engine algorithm can learn consumers' preferences, and the more relevant the search results will likely become. These factors will likely attract others to use the search engine, and the positive feedback continues. ${ }^{39}$

These data-driven network effects can magnify the competitive stakes in winning or losing customers. Ordinarily, the effect is the gain or loss in sales. The quality of the leading brand's razors, for example, is not affected when consumers switch from rival razors. In contrast, with datadriven network effects, the gain or loss in users can affect the product's or service's quality. The data-opolies' personal digital assistants, for example, can improve in quality as more users engage with the digital assistant and as more developers develop skills for that assistant. While data-opolies might innovate, a significant part of the quality gains may come simply from network effects by users and developers.

Thus, it superficially appears that through a price lens, data-opolies pose little risk, if any, of antitrust harm. Unlike other monopolies, especially in the pharmaceutical industry, ${ }^{40}$ data-opolies do not charge consumers exorbitant prices. Quality can increase from network effects. And the risk of a deadweight welfare loss or wealth transfer from these "free" products and services appears minimal.

\section{Potential Harms From DATA-OPOLIES}

One could further argue that the Sherman Act's term "monopolize" involves only economic phenomena. Antitrust's sole objective, then, is to promote allocative efficiency. Using the antitrust laws for goals unrelated or antithetical to efficiency is unjustifiable. Thus, without traditional economic evidence of economic harm (e.g., higher prices, less output), data-opolies are, from an antitrust perspective, benign (or at least beyond the reach of section 2 of the Sherman Act).

This reasoning has several flaws. Despite some claims to the contrary, ${ }^{41}$ the antitrust agencies recognize that the "fact that a product or

\footnotetext{
${ }^{39}$ StUCKe \& GRUNES, BIG DATA AND COMPETITION Policy, supra note 1, at 172-81; see also Google Shopping Search, supra note 3, at 1 甲 286-89.

${ }^{40}$ Associated Press, Drug Prices Don't Budge Even After Pressure from Congress, STAT NEws (Nov. 16, 2016), https://www.statnews.com/2016/11/16/drug-prices-congresspressure/ [https://perma.cc/8W77-J952].

${ }^{41}$ See, e.g., Kinderstart.com LLC v. Google, Inc., No. C06-2057JFRS, 2007 WL 831806, at *5 (N.D. Cal. Mar. 16, 2007) ("KinderStart cites no authority indicating that antitrust
} 
service is provided free of charge does not prevent the offering of such a service from constituting an economic activity for the purposes of [their] competition rules." 42 The United States has challenged anti-competitive restraints when the product is free. For example, when the leading free alternative newsweeklies illegally allocated markets, readers were harmed, even though the publications were free. ${ }^{43}$ But even though users do not pay money for the use of the data-opolies' "free" services, they are not really free. Users, the European Commission found, "contribute to the monetisation of the service by providing data." platforms does not have to be money. In many cases, it is data.

Second, the assumption that antitrust's primary goal is to maximize allocative efficiency or minimize the deadweight welfare loss is dubious. ${ }^{45}$ As the economist George Stigler said, "A careful student of the history of economics would have searched long and hard, on July 2 of 1890, the day the Sherman Act was signed by President Harrison, for any economist who had ever recommended the policy of actively combating collusion or monopolization in the economy at large. ${ }^{, 46}$ Senator John Sherman, among others, criticized trusts and monopolies for many things, but not their deadweight welfare loss. ${ }^{47}$

law concerns itself with competition in the provision of free services. Providing search functionality may lead to revenue from other sources, but KinderStart has not alleged that anyone pays Google to search. Thus, the Search Market is not a 'market' for purposes of antitrust law.").

${ }^{42}$ Google Shopping Search, supra note 3, at 152. Germany in 2017 amended its competition law to clarify that the "assumption of a market shall not be invalidated by the fact that a good or service is provided free of charge." Act against Restraints of Competition [Competition Act - GWB], May 6, 2018, $\S 18$ (2a), https://www.bundeskartellamt.de/SharedDocs/Publikation/EN/Others/GWB.pdf [https://perma.cc/9RE6-Q5JT].

${ }^{43}$ See, e.g., Complaint filed in United States v. Village Voice Media, LLC, No. 1:03CV0164 (N.D. Ohio filed Jan. 27, 2003), https:/www.justice.gov/atr/casedocument/file/515441/download [https://perma.cc/484Q-7FY7]; see also OECD, Big Data: Bringing Competition Policy to the Digital Era: Background Note by the Secretariat, at 18, DAF/COMP(2016)14 (Apr. 26, 2017), https://one.oecd.org/document/DAF/COMP(2016)14/en/pdf [https://perma.cc/JG2TZ3DG] [hereinafter OECD Big Data Report] ("Competition authorities have generally recognised the importance of quality as a competitive feature, especially when the product or service is offered for free.").

${ }_{45}^{44}$ Google Shopping Search, supra note 3, at 158.

${ }^{45}$ See Ariel Ezrachi, Sponge, 5 J. AnTitrust EnF'T 49 (2017); see also Maurice E. Stucke, Reconsidering Antitrust's Goals, 53 B.C. L. REV. 551 (2012).

${ }^{46}$ George J. Stigler, The Economists and the Problem of Monopoly, 72 AM. ECON. REV. 1, 3 (1982).

${ }^{47}$ See, e.g., Robert H. Lande, Wealth Transfers as the Original and Primary Concern of Antitrust: The Efficiency Interpretation Challenged, 50 HASTINGS L.J. 871, 894 (1999) (internal footnotes omitted): 
Finally, in looking beyond the "free" price, this Part identifies several significant potential antitrust harms involving data-opolies, such as degraded quality, surveillance and security risks, wealth transfers, loss of trust, significant costs on third parties, less innovation, less autonomy, and political risks.

\title{
A. Degraded Quality
}

Although antitrust enforcers in the past few decades have focused on price effects, one long-standing and well-accepted concern of market power, generally, and monopolies, in particular, is degraded quality. ${ }^{48}$ While data-opolies' quality can increase on some parameters, quality can deteriorate on other important parameters of competition, such as privacy protection. ${ }^{49}$ A data-opolist, to the extent its business model depends on

\begin{abstract}
More importantly, leading economists of the day had very little influence on the passage of the Act. It is unlikely, then, that the legislators who passed the early antitrust laws were aware that monopoly pricing led to allocative inefficiency. Nothing in the legislative history of the Sherman Act suggests that they were. No commentator has pointed to any economic testimony that referred to a concept resembling "allocative efficiency," nor is there the slightest evidence that any member of Congress was even remotely familiar with this type of welfare loss.
\end{abstract}

${ }^{48}$ U.S. DeP’T OF JuST. \& F.T.C., Horizontal Merger Guidelines $§ 1$ (Aug. 19, 2010), https://www.justice.gov/atr/horizontal-merger-guidelines-08192010 ("Enhanced market power can also be manifested in non-price terms and conditions that adversely affect customers, including reduced product quality, reduced product variety, reduced service, or diminished innovation. Such non-price effects may coexist with price effects, or can arise in their absence."); OECD, The Role and Measurement of Quality in Competition Analysis, at 22, $\operatorname{DAF} / \operatorname{COMP}(2013) 17$ (Oct. 28, 2013), http://www.oecd.org/competition/Quality-in-competition-analysis-2013.pdf

[https://perma.cc/7R2K-B3DX] [hereinafter OECD Background Note]; Google Shopping Search, supra note 3, \324 (Google, the European Commission found, "could alter the quality of its general search service to a certain degree without running the risk that a substantial fraction of its users would switch to alternative general search engines."); see also Maurice E. Stucke \& Ariel Ezrachi, When Competition Fails to Optimize Quality: A Look at Search Engines, 18 YALE J.L. \& TECH. 70 (2016).

${ }^{49}$ European Commission Press Release IP/16/4284, Mergers: Commission Approves Acquisition of LinkedIn by Microsoft, Subject to Conditions (Dec. 6, 2016), http://europa.eu/rapid/press-release_IP-16-4284_en.htm [https://perma.cc/RU3N-TEXX] ("[T] he Commission concluded that data privacy was an important parameter of competition between professional social networks on the market, which could have been negatively affected by the transaction."); Microsoft/LinkedIn Decision, at 950 (Dec. 6, 2016) ("[T] $]$ the extent that these foreclosure effects would lead to the marginalisation of an existing competitor which offers a greater degree of privacy protection to users than 
harvesting and exploiting personal data, has the incentive to reduce its privacy protection below competitive levels and collect personal data above competitive levels.

This concerned Germany's competition authority. Facebook, the Bundeskartellamt found in its preliminary assessment, abused its dominant position "by making the use of its social network conditional on its being allowed to limitlessly amass every kind of data generated by using thirdparty websites and merge it with the user's Facebook account.. ${ }^{, 50}$ As the agency head, Andreas Mundt, said,

Data protection, consumer protection and the protection of competition interlink where data, as in Facebook's case, are a crucial factor for the economic dominance of a company. On the one hand the social network offers a free service, on the other it offers attractive advertising space, which is so valuable because Facebook has huge amounts of personalised data at its disposal. In these entrepreneurial activities Facebook has to comply with rules and laws. Competition law prohibits a company from abusing its market power. ${ }^{51}$

LinkedIn (or make the entry of any such competitor more difficult), the transaction would also restrict consumer choice in relation to this important parameter of competition when choosing" a professional social network); Eleonora Ocello \& Cristina Sjödin, Microsoft/LinkedIn: Big Data and Conglomerate Effects In Tech Markets, EUR. COMMISSION: COMPETITION MERGER BRIEF, May 2017, at 5, http://ec.europa.eu/competition/publications/cmb/2017/kdal17001enn.pdf

[https://perma.cc/F57F-HZWR] (discussing how the foreclosure of competing networks post-merger could adversely impact the choice of consumers as to the level of data protection offered, as some competitors offered a greater degree of privacy protection to users than LinkedIn); OECD Big Data Report, supra note 43, at 14, 18; OECD, Summary of Discussion of the Hearing on Big Data: Annex to the Summary Record of the 126th Meeting of the Competition Committee Held on 29-30 November 2016, at 5, DAF/COMP/M(2016)2/ANN2 (Mar. 22, 2017) (European Commission noting that "data protection as a measure of quality can potentially be an important aspect of competition policy, though it is not necessarily an aspect that matters for all consumers") [hereinafter OECD Annex]; Robert H. Lande, The Microsoft-Yahoo Merger: Yes, Privacy is an Antitrust Concern, FTC: WATCH No. 714 (2008), https://ssrn.com/abstract=1121934 [https://perma.cc/MW47-Z4ZS].

50 Bundeskartellamt Press Release: Preliminary Assessment in Facebook Proceeding: Facebook's Collection and Use of Data from Third-Party Sources Is Abusive (Dec. 19, 2017),

https://www.bundeskartellamt.de/SharedDocs/Meldung/EN/Pressemitteilungen/2017/19 12_2017_Facebook.html [https://perma.cc/Q2QV-UD8P] (These third-party sites included services owned by Facebook such as WhatsApp or Instagram and websites and apps of other operators with embedded Facebook APIs.).

${ }^{51} I d$. 
Because the Bundeskartellamt's assessment is preliminary, Facebook can formally respond. A final decision is expected later in 2018. But its preliminary assessment raises several interesting observations about the privacy harm.

First, the collection of too much data can be the equivalent of charging an excessive price. Although the Bundeskartellamt's claim rested on unfair business terms, ${ }^{52}$ Facebook's data collection was exploitive. The volume and variety of personal data that users relinquished was worth far more than what users received in exchange. Enforcers, if relying solely on their price-centric tools, would miss this harm.

Competition authorities generally define markets and assess market power using a SSNIP test, which asks whether a hypothetical monopolist can impose a small, but significant, nontransitory increase in price. ${ }^{53}$ The SSNIP test is hard to apply when the product or service is ostensibly free. ${ }^{54}$ It may also be less relevant. For data-opolies, a more germane test would be a SSNDPP — a small, but significant, nontransitory decrease in privacy protection. ${ }^{55}$ In markets where many consumers are

52 The Bundeskartellamt preliminarily found that Facebook made the use of its social network services "conditional upon the user granting the company extensive permission to use his or her personal data." So the competition agency challenged this as "exploitative business terms." The damage for the users "lies in a loss of control: they are no longer able to control how their personal data are used." Bundeskartellamt, Background Information on the Facebook Proceeding (Dec. 19, 2017), https://www.bundeskartellamt.de/SharedDocs/Publikation/EN/Diskussions_Hintergrundp apiere/2017/Hintergrundpapier_Facebook.pdf [https://perma.cc/EUU6-QYNY].

${ }^{53}$ HorizOnTAL MERGER GUIDELINES, supra note $48, \S 4.1 .1$.

${ }^{54}$ Google Shopping Search, supra note 3, I 245 ("SSNIP test would not have been appropriate in the present case because Google provides its search services for free to users"); John M. Newman, Antitrust in Zero-Price Markets: Applications, 94 WASH. U.L. REV. 49, 65 (2016) ("This analytical framework loses its coherence in zero-price markets, where the basic unit of value extracted from customers is not expressed as a price."); Michal S. Gal \& Daniel L. Rubinfeld, The Hidden Costs of Free Goods: Implications for Antitrust Enforcement, 80 ANTITRUST L.J. 521, 549 (2016) ("SSNIP test does not capture the competitive constraints on the firm offering the free good, which often accrue in a companion market"); Nate Bush, Lining Shan, \& Ning Qiao, Qihoo Versus Tencent: Roadmap or Anomaly?, 29 ANTITRUST 2, 54, 56 (Spring 2015) (discussing how China's Supreme People's Court, in a dispute between Internet giants Tencent and Qihoo, found the "conventional SSNIP test inappropriate in markets for free IM and security software services since any price would represent an infinite increase" and how the Court "suggested that other hypothetical monopolist methodologies focused on quality and consumer experience (such as a 'small but significant and non-transitory decrease in quality' test) would be more appropriate, even though they entailed greater reliance on qualitative rather than quantitative analyses").

${ }^{55}$ The French competition authority, for example, noted:

the collection of consumer data has brought a price for the use of online platforms that used to be free in the past. Hence, in the same way 
concerned about the collection and use of their personal data, privacy protection may be of greater relevance.

One illustration is Facebook's acquisition of the rival texting app, WhatsApp. WhatsApp, pre-acquisition, charged some users $\$ 0.99$ annually for its texting app. ${ }^{56}$ Asking whether a hypothetical monopolist could profitably raise the texting app's fee to $\$ 1.05$ does not shed light on the market dynamics. WhatsApp users may be more concerned about the privacy degradation post-merger than paying an extra nickel. And the value of the WhatsApp data to Facebook was likely worth far more than the incremental profit from that SSNIP. Not surprisingly, WhatsApp's and Facebook's senior management, post-merger, clashed over the level of data privacy (i.e., a SSNDPP) and not on whether to impose any price increase on users (i.e., a SSNIP). ${ }^{57}$

Second, besides degrading privacy protection, a data-opoly faces little competitive pressure to change an opaque privacy policy. ${ }^{58}$ The Bundeskartellamt focused on how Facebook collected and processed its users' personal data even when users visited other third-party websites. For example, if a Facebook user goes to the New York Times website, personal data is collected even when "a user does not press a 'like button' but has called up a site into which such a button is embedded." ${ }^{, 59}$ Users were unaware of the extent of Facebook's tracking and data collection. ${ }^{60}$

mergers are assessed based on their potential effects on prices, merger review should also account for the risk of increased transfers of data. For that, traditional factors should be considered, such as whether there are potential entrants exerting competitive pressure and whether firms compete, in fact, on privacy / confidentially dimensions.

OECD Annex, supra note 49, at 4.

${ }^{56}$ Alex Hern, WhatsApp Drops Subscription Fee to Become Fully Free, GUARDIAN (Jan. 18 , 2016), https://www.theguardian.com/technology/2016/jan/18/whatsapp-dropssubscription-fee-free [https://perma.cc/FW8T-F4G7].

${ }^{57}$ Kirsten Grind \& Deepa Seetharaman, Behind the Messy, Expensive Split Between Facebook and WhatsApp's Founders, WALL ST. J. (June 5, 2018), https://www.wsj.com/articles/behind-the-messy-expensive-split-between-facebook-andwhatsapps-founders-1528208641 [https://perma.cc/65LA-TKNG].

${ }^{58}$ OECD Annex, supra note 49, at 6 (United Kingdom competition authority expressing "concerns that firms may have few incentives for transparency in the absence of some regulatory response, and that a lack of confidence by consumers may eventually undermine the market").

${ }^{59}$ Bundeskartellamt Press Release: Preliminary Assessment in Facebook Proceeding: Facebook's Collection and Use of Data from Third-Party Sources Is Abusive (Dec. 19, 2017),

https://www.bundeskartellamt.de/SharedDocs/Meldung/EN/Pressemitteilungen/2017/19 12_2017_Facebook.html [https://perma.cc/A2VX-5YC7].

${ }^{60}$ Bundeskartellamt, Background Information on the Facebook Proceeding (Dec. 19, 2017), 
As the OECD noted, "by keeping privacy policies deliberately vague, service providers make it difficult for consumers to evaluate the real value of their data. The user is given the immediate benefit of the zero-price service but is unaware of the short or long-term costs of divulging information because they do not know how the data will be used and by whom." ${ }^{\prime 61}$ Thus, if a data-opoly states in its privacy statement that the data it collects across its products and services are used for advertising purposes, is this sufficient disclosure to infer consent? ${ }^{62}$ Unlikely. At the practical level, consent is meaningless if users are unaware what data is collected, how their personal data will be used, and by whom. ${ }^{63}$

Third, even if the data-opoly clearly discloses the data it collects and its (and third-parties') use of the data, the notice-and-consent regime is meaningless when bargaining power is so unequal that users do not have a viable alternative option. Data-opolies usually grant service on a "takeit-or-leave-it" basis. ${ }^{64}$ Facebook simply gave its users the choice "of either accepting the "whole package' or doing without the service." ${ }^{\prime 65}$ Potential users often have little choice but to agree. Unless their friends and

http://www.bundeskartellamt.de/SharedDocs/Publikation/EN/Diskussions_Hintergrundpa piere/2017/Hintergrundpapier_Facebook.pdf [https://perma.cc/VHY4-U7SL]. One 2017 study sought to identify who tracked users as they surfed the Web. The study examined over 144 million page loads in over 12 countries, including the United States, Canada, Great Britain, France, Germany, Austria and Switzerland. The study found that "at least one tracker was prowling around 77.4 percent of the tested page loads." Google and Facebook, by far, led in tacking users. Their tracking tools were found on 60.3 percent and 27.1 percent, respectively, of the websites examined. They were followed by ComScore (11.4 percent) and Twitter (10.5 percent). Cliqz \& Ghostery, Tracking the Trackers: Analyzing the Global Tracking Landscape with GhostRank, CLIQZ (June 12, 2017), https://cliqz.com/en/magazine/ghostery-study [https://perma.cc/M2XF-BCE7].

${ }_{62}^{61}$ OECD Big Data Report, supra note 43, at 25.

62 Amazon, Inc., Amazon Privacy Notice, https://www.Amazon.com/gp/help/customer/display.html?nodeId=468496\#GUID1B2BDAD4-7ACF-4D7A-8608-

CBA6EA897FD3_SECTION_87C837F9CCD84769B4AE2BEB14AF4F01

[https://perma.cc/3CLP-E6BV].

${ }^{63}$ Julie E. Cohen, Examined Lives: Informational Privacy and the Subject as Object, 52 STAN. L. REV. 1373, 1433 (2000) (noting how consent cannot be meaningful as to unknown uses or unspecified recipients, so effective data privacy legislation "should require that individuals be given specific information, and the opportunity to consent or refuse, as to each contemplated reuse or transfer").

${ }^{64}$ Tom Symons \& Theo Bass, Me, My Data And I: The Future of the Personal DATA ECONOMY, 13, 20 (Sept. 2017), https://decodeproject.eu/publications/me-my-dataand-ithe-future-personal-data-economy [https://perma.cc/AWR9-6NBN].

${ }^{65}$ Bundeskartellamt Press Release: Preliminary Assessment in Facebook Proceeding: Facebook's Collection and Use of Data from Third-Party Sources Is Abusive (Dec. 19, 2017),

https://www.bundeskartellamt.de/SharedDocs/Meldung/EN/Pressemitteilungen/2017/19 12_2017_Facebook.html [https://perma.cc/HPX2-AWD9]. 
relatives all switch to another social network, any one individual cannot feasibly switch without sacrificing the ability to interact with family and friends, a core function of any social network. Given Facebook's dominant position, the German competition agency could not assume "that users effectively consent to this form of data collection and processing."

Consequently, as the Bundeskartellamt assessed, market forces will not necessarily provide the optimal level of privacy or data protection. Monopoly power is a well-accepted market failure. ${ }^{67}$ Network effects and other entry barriers protect data-opolies from many forms of competition. As a result, they can depress an important parameter of non-price competition, privacy protection, below competitive levels and collect personal data above competitive levels. Adults in the United States, as of mid-2018, do not have a general legal right to review the personal information a dominant firm collects about them, revoke their consent, refuse the further use or collection of personal information, or have their personal information deleted. ${ }^{68}$ When it is against the data-opolies' economic interest to provide users greater protection or control over their personal data, privacy will suffer.

\section{B. Surveillance and Security Risks}

Granted, privacy concerns also exist in unconcentrated markets. Data breaches, for example, occur in firms without market power. But, at least in those markets, personal data is generally dispersed across many firms, and competitive pressure may serve to curtail the providers' ability to degrade privacy. In contrast, in monopolized markets, personal data is concentrated in a few firms, and consumers have limited outside options that offer better privacy protection.

This raises several risks. One risk is government capture. On the one hand, data-opolies may possess the power and incentive to thwart

\footnotetext{
${ }^{66} I d$.

${ }^{67}$ See, e.g., Oren Gazal-Ayal, Economic Analysis of Standard Form Contracts: The Monopoly Case, 24 EUR. J.L. \& ECON. 119 (2007) (showing that when suppliers can adjust the content of the form contract, the few reading consumers cannot correct the market failure: "In fact, unless all consumers read and understand the form contract, a monopoly is always encouraged to offer sub-optimal terms, i.e., terms that benefit her but at a higher cost to the consumers.").

${ }^{68}$ The Children's Online Privacy Protection Act of 1998, which affords these protections, applies to data collected about children under thirteen years old. See Children's Online Privacy Protection Rule, 16 C.F.R. $\S 312.2$ (2017). But things might change, after California will afford residents greater privacy protection, with a law that goes into effect in 2020. Marc Vartabedian, California Passes Sweeping Data-Privacy Bill, WaLl St. J. (June 28, 2018, 9:36 PM), https://www.wsj.com/articles/california-rushes-to-tighten-dataprivacy-restrictions-1530190800 [https://perma.cc/6QKW-T23M].
} 
government surveillance. ${ }^{69}$ On the other hand, the fewer the number of firms controlling the personal data, the greater the risk that a government will "capture" the firms using its many levers. ${ }^{70}$ Companies need things from the government; governments often want access to data. When there are only a few firms, this can increase the likelihood of companies secretly cooperating with the government to provide access to data. Moreover, a dominant firm is likely to lobby the government on many more fronts. ${ }^{71}$ This also increases the likelihood of cooperation with governments where doing so yields greater benefits on these other fronts. China, for example, relies on its data-opolies to better monitor its population. "The data these companies collect is richer and thicker than what the government can collect, so the typical case now is the government going to the companies to get information," said the managing editor of Asia Global Institute. ${ }^{73}$ "This shows how much power the companies hold." "74

Concentrated economic and political power is a dangerous mix. We saw this in Nazi Germany. ${ }^{75}$ As personal data is dispersed across

${ }^{69}$ See Dep't of State, Bureau of Democracy, H.R., And Lab., Egypt 2016 Human RigHTS REPORT, 2017 WL 1063649 (Mar. 2017) (noting that "in December 2015 Facebook terminated its Free Basics Service, which provided mobile phone users with free access to a limited suite of internet services, because the company would not allow the government to circumvent the service's security to conduct surveillance"); Alan Z. Rozenshtein, Surveillance Intermediaries, 70 STAN. L. REV. 99, 185 (2018) (arguing how "surveillance intermediaries, the small group of giant technology companies that provide the vast majority of consumer digital communications and data processing services, meaningfully constrain the government's ability to conduct electronic surveillance").

${ }^{70}$ Kelton Sears, Alexa and the Dawn of So-What Surveillance, SEATTLE WEekLY (Mar. 29, 2017, 1:30 AM), http://www.seattleweekly.com/news/alexa-and-the-dawn-of-sowhat-surveillance/ [https://perma.cc/7YKK-8NZ3].

${ }^{71}$ Brian Fung \& Hamza Shaban, To Understand How Dominant Tech Companies Are, See What They Lobby For, L.A. TIMES (Sept. 1, 2017, 12:55 PM), http://www.latimes.com/business/technology/la-fi-tn-silicon-valley-lobbying-20170901story.html [https://perma.cc/YL6R-XSXZ].

${ }^{72}$ One example is Tencent Holdings Ltd. launching with the Ministry of Public Security a pilot digital identification system. Alyssa Abkowitz, The Internet Tightens: Popular Chinese WeChat App to Become Official ID, WALl St. J. (Dec. 31, 2017, 7:27 PM), https://www.wsj.com/articles/internet-tightens-popular-chinese-wechat-app-to-becomeofficial-id-1514541980 [https://perma.cc/47AM-5C22].

${ }^{73} I d$.

${ }^{74} I d$.

${ }^{75}$ See, e.g., Letter from Franklin D. Roosevelt, President of the U.S., to Cordell Hull, Sec'y of State, Letter on the Elimination of Cartels (Sept. 6, 1944), http://www.presidency.ucsb.edu/ws/?pid=16554 [https://perma.cc/BU69-MUNJ] [hereinafter FDR Letter]:

During the past half century the United States has developed a tradition in opposition to private monopolies. The Sherman and Clayton Acts have become as much a part of the American way of life as the due 
many more firms and industries, there are more firms that the government must bribe or coerce to access data. As the number of bribes increase, the lower the likely value of each bribe, which reduces the odds that a firm will accept the bribe in exchange for the personal data.

A second risk is covert surveillance. Even if the government cannot capture the data-opoly directly, its rich data-trove increases a government's incentive to circumvent the data-opoly's privacy protections to tap into the personal data. ${ }^{76}$ This privacy concern also arises in unconcentrated markets. But, at least in those markets, personal data would be dispersed across many firms, and each firm, given robust privacy competition, might have less personal data.

A third risk is the implications of a data policy violation or security breach. Given the personal data's value, a data-opoly has a significant financial incentive to safeguard the data. But with more personal data concentrated in fewer companies, hackers, marketers, political consultants, and others have even greater incentives to find ways to circumvent or breach the dominant firm's security measures. ${ }^{77}$ The concentration of data

process clause of the Constitution. By protecting the consumer against monopoly these statutes guarantee him the benefits of competition.

....

Unfortunately, a number of foreign countries, particularly in continental Europe, do not possess such a tradition against cartels. On the contrary, cartels have received encouragement from some of these Governments. Especially is this true with respect to Germany. Moreover, cartels were utilized by the Nazis as governmental instrumentalities to achieve political ends. The history of the use of the I. G. Farben trust by the Nazis reads like a detective story. The defeat of the Nazi armies will have to be followed by the eradication of these weapons of economic warfare. But more than the elimination of the political activities of German cartels will be required. Cartel practices which restrict the free flow of goods in foreign commerce will have to be curbed.

\footnotetext{
${ }^{76}$ See, e.g., Barton Gellman \& Ashkan Soltani, NSA Infiltrates Links to Yahoo, Google Data Centers Worldwide, Snowden Documents Say, WASH. Post (Oct. 30, 2013), https://www.washingtonpost.com/world/national-security/nsa-infiltrates-links-to-yahoogoogle-data-centers-worldwide-snowden-documents-say/2013/10/30/e51d661e-416611e3-8b74-d89d714ca4dd_story.html [https://perma.cc/ZRY8-CSHK]. One example, according to the recent WikiLeaks, is the Central Intelligence Agency's "Weeping Angel" program. The CIA hacked smart televisions, transforming them into covert microphones. The CIA could also remotely hack and control popular smartphones, which could be instructed to send the CIA "the user's geolocation, audio and text communications as well as covertly activate the phone's camera and microphone." Press Release, WikiLeaks, Vault 7: CIA Hacking Tools Revealed (Mar. 7, 2017), https://wikileaks.org/ciav7p1/ [https://perma.cc/M6E2-VEE7].

${ }^{77}$ See, e.g., Facebook, Inc., Annual Report 13 (Form 10-K) (Feb. 1, 2018) (“As a result of our prominence, the size of our user base, and the types and volume of personal data
} 
means that if one of them is breached, the harm done could be orders of magnitude greater than with a normal company. Consumers may express outrage over a policy violation, as was the case with Cambridge Analytica, or a data breach. But data-opolies, protected by network effects and other barriers, will have less reason to worry about consumers switching to a rival platform. Indeed, despite the \#DeleteFacebook campaign, Facebook, in its first quarter of 2018, saw a thirteen percent increase in daily and monthly active users and a forty-nine percent increase in revenue, yearover-year. ${ }^{78}$

A fourth risk is the continuing privacy harm. Even if users decide to switch e-mail accounts, for example, the data collected on them is now part of their consumer profile that can be sold to third-parties or used internally for behavioral advertising or price discrimination. When the data is merged with other data sets (or used for other purposes), new private details about the individual can be gleaned and exploited. ${ }^{79}$

\section{Wealth Transfer to Data-opolies}

One concern that prompted the Sherman Act in 1890 was the distributional effects of market power. President Grover Cleveland observed in 1888 that with executives "madly striving in the race for riches," income disparities increased, creating two distinct classes: "one comprising the very rich and powerful, while in another are found the toiling poor." ${ }^{\prime \prime 0}$ Senator Sherman identified this inequality of condition, wealth, and opportunity as the greatest threat of disturbance to social order. $^{81}$

Even when their products and services are ostensibly "free," dataopolies can still extract wealth on several levels. As The Economist reported, "Alphabet [Google], Facebook and Amazon are not being valued by investors as if they are high risk, but as if their market shares are

on our systems, we believe that we are a particularly attractive target for such [data] breaches and attacks.") [hereinafter Facebook 2018 10-K].

78 Facebook, Inc., Quarterly Report 24 (Form 10-Q) (Apr. 26, 2018), https://d18rn0p25nwr6d.cloudfront.net/CIK-0001326801/c867f5bf-e958-4d4d-bbd0cfb1caae55a3.pdf [https://perma.cc/W77V-MRVL].

${ }^{79}$ OECD Big Data Report, supra note 43, at 6.

${ }^{80}$ Grover Cleveland, President of the United States, Fourth Annual Message (Dec. 3, 1888), reprinted in 1 Earl W. Kintner, The Legislative History of the Federal ANTITRUST LAWS AND RELATED STATUTES 58 (1978).

8121 CONG. REC. 2455, 2460 (1890) (This inequality "has grown within a single generation out of the concentration of capital into vast combinations to control production and trade and to break down competition."). 
sustainable and their network effects and accumulation of data will eventually allow them to reap monopoly-style profits. ${ }^{, 82}$

First, the data-opoly can extract wealth by getting personal data, including users' likes, dislikes, intentions, and so on, without having to pay for the data's fair market value. ${ }^{83}$ Ostensibly, many data-opolies provide their services for "free." However, the personal data collected may be worth far more than the cost of providing the "free" service. As the OECD noted:

Google's vast and ongoing investments to continuously develop new products that are offered to users at a zero price also reflect the perceived value of data. By combining all the data collected through Android and other products, and using its own algorithms as well as machine-learning programmes, Google is able to enhance its detailed user profiles with information that no other competitor has and which should be valuable enough to recover the money invested. $^{84}$

82 Too Much of a Good Thing, ECONOMIST (Mar. 26, 2016), https://www.economist.com/news/briefing/21695385-profits-are-too-high-america-needsgiant-dose-competition-too-much-good-thing [https://perma.cc/L8TJ-PN6E].

${ }_{83}^{83}$ SYMONS \& BASS, supra note 64, at 17.

${ }^{84}$ OECD Big Data Report, supra note 43, at 9. The more personal data a company collects, the greater the variety of the data, and the faster the company can collect and process the data, the greater the potential value of the data. This provides data-opolies a significant competitive advantage. Newspapers now depend on data-opolies for traffic to their websites. See Rasmus Kleis Nielsen \& Sarah Anne Ganter, Dealing with Digital Intermediaries: A Case Study of the Relations between Publishers and Platforms, 20 NEW MEDIA \& SOC'Y 1600, 1601 (2018), http://journals.sagepub.com/eprint/dxNzFHygAIRHviKP9MFg/full

[https://perma.cc/6WCZ-7KUR] (noting how a "growing number of news organizations across the world report that only about half their online traffic comes direct to their website and app, with the rest coming from search and social referrals"). A publisher, for example, may know what articles its readers "like" using the Facebook tool. But Facebook also knows this. Facebook can also follow these users across its own platform, including WhatsApp and Instagram, and across the web to any website with embedded Facebook APIs. So, a significant information asymmetry arises between data-opolies and other advertising vehicles. See, e.g., id. at 1611-12 (noting how the divide between those who have and those who do not have access to detailed data goes not only between individual users and large technology companies but also between, for example, platforms and publishers); see also Bundeskartellamt, Background Information on the Facebook Proceeding (Dec. 19, 2017), http://www.bundeskartellamt.de/SharedDocs/Publikation/EN/Diskussions_Hintergrundpa piere/2017/Hintergrundpapier_Facebook.pdf [https://perma.cc/BS48-CCUD] ("Facebook has superior access to the personal data of its users and other competition-relevant data. Because social networks are data-driven products, access to such data is an essential 
The fact that the service is "free" does not mean users are fairly compensated for their data and content. ${ }^{85}$ Suppose in a competitive market, the personal data is worth $\$ 10$. In exchange for this data, a company offers services that are worth $\$ 1$. Ordinarily, a user would decline and opt for another service provider that (i) pays a fair price for the data (i.e., provides the "free" service plus $\$ 9$ in consideration), (ii) provides greater value in return, or (iii) collects less personal data. As several European Commission officials observed, if a website, postmerger, "would start requiring more personal data from users or supplying such data to third parties as a condition for delivering its 'free' product" then this "could be seen as either increasing its price or as degrading the quality of its product." $" 86$ Thus, data-opolies have a strong economic incentive to maintain the profitable status quo, where users "have little idea how much personal data they have provided, how it is used, and what it is worth." 87

A second way data-opolies can extract wealth is by getting creative content from users for free. In a consumer-oriented competitive market, users could conceivably demand compensation not only for their data but also their contributions to YouTube and Facebook. Yet, data-opolies have diluted this power. Users effectively work for free for the data-opoly by

factor for competition in the market. The data are relevant for both, the product design and the possibility to monetize the service. If other companies lack access to comparable data resources, this can be an additional barrier to market entry."); Tom Simonite, What Facebook Knows, MIT TECH. REV. (June 13, 2012), https://www.technologyreview.com/s/428150/what-facebook-knows/

[https://perma.cc/N63F-ZLR2].

${ }^{85}$ Eduardo Porter, Your Data is Crucial to a Robotic Age. Shouldn't You be Paid for It?, N.Y. TIMES (Mar. 6, 2018), https://www.nytimes.com/2018/03/06/business/economy/user-data-pay.html [https://perma.cc/P2AM-TBSR]; Tom Simonite, Sell Your Personal Data for $\$ 8$ a Month, MIT TECH. REV. (Feb. 12, 2014), https://www.technologyreview.com/s/524621/sellyour-personal-data-for-8-a-month/ [https://perma.cc/FJ88-QDYL].

${ }^{86}$ Eleonora Ocello et al., What's Up with Merger Control in the Digital Sector? Lessons from the Facebook/WhatsApp EU Merger Case, COMPETITION MERGER BRIEF, Feb. 2015 at 2 ,

6 , http://ec.europa.eu/competition/publications/cmb/2015/cmb2015_001_en.pdf [https://perma.cc/Y29C-BMXA]; Report of Study Group on Data and Competition Policy (Summary), JAPAN FAIR TRADE COMM'N (June 6, 2017), https://www.jftc.go.jp/en/pressreleases/yearly-2017/June/170606.html

[https://perma.cc/YMU8-BXCU]; OECD Big Data Report, supra note 43, at 16-17 ("market power may be exerted through non-price dimensions of competition, allowing companies to supply products or services of reduced quality, to impose large amounts of advertising or even to collect, analyze or sell excessive data from consumers").

${ }^{87}$ Tom Simonite, If Facebook Can Profit from Your Data, Why Can't You?, MIT TeCH. REV. (July 30, 2013), https://www.technologyreview.com/s/517356/if-facebook-canprofit-from-your-data-why-cant-you/ [https://perma.cc/B9EL-XJ34]. 
posting content, commenting on other people's content, and supporting the advertisers. Data-opolies capitalize on the content users post to attract others to their platform.

Facebook notes how the size of its user base and its users' level of engagement are critical to its success. ${ }^{88}$ Facebook users' postings attract others to the social network. It is doubtful that Facebook would be as popular if another large social network compensated users for posting content and spending time on its platform. Indeed, Facebook users are effectively free endorsers when they "like" a product, advertisement, or company. Unless they specifically opt-out, users' photo and identity can be used in that product's advertisements targeted at friends, family, and others. ${ }^{89}$ If data serfs (i.e., the users) stopped toiling away for free, then the quality and frequency of postings would decrease, and Facebook's profit would likely shrink. But, if due to network effects, no viable alternative social network exists, then the data-opoly has less to fear from exploiting user-generated content on its platform.

A third way data-opolies can extract wealth is from sellers and suppliers upstream. At times, antitrust considers consumers and sellers as distinct groups. But concentrated economic power, as the Sherman Act's legislative history reflects, can operate with a doubled-edged sword in harming citizens as buyers and sellers. ${ }^{90}$ So too, data-opolies can

\footnotetext{
${ }^{88}$ Facebook 2018 10-K, supra note 77, at 8 ("If we fail to retain existing users or add new users, or if our users decrease their level of engagement with our products, our revenue, financial results, and business may be significantly harmed.").

${ }^{89}$ Vindu Goel, Flipping the Switches on Facebook's Privacy Controls, N.Y. TIMES (Jan. 29, 2014), https://www.nytimes.com/2014/01/30/technology/personaltech/on-facebookdeciding-who-knows-youre-a-dog.html [https://perma.cc/M4N4-G7BJ] (noting that "Facebook users effectively are free endorsers when they 'like' a product, advertisement, or company; their photo and identity can now be used in that product's advertisements targeted at friends, family, and others"). As Facebook tells its users, "People want to know what their friends like. That's why we show ads to your friends based on actions you take, such as liking a Page or sharing a post." Facebook, Your Ad Preferences, https://www.facebook.com/ads/preferences/?entry_product=ad_settings_screen [https://perma.cc/348S-288N]. Users have to specifically opt out of this feature.

${ }^{90} 21$ CONG. REC. 2455, 2461 (1890) (statement of Sen. John Sherman):
}

These trusts and combinations ... increase beyond reason the cost of the necessaries of life and business, and they decrease the cost of the raw material, the farm products of the country. They regulate prices at their will, depress the price of what they buy and increase the price of what they sell. They aggregate to themselves great, enormous wealth by extortion which makes the people poor. Then, making this extorted wealth the means of further extortion from their unfortunate victims, the people of the United States, they pursue unmolested, unrestrained by law, their ceaseless round of peculation under the law, till they are fast producing that condition in our people in which the great mass of 
aggregate "to themselves great, enormous wealth by extortion which makes the people poor." "91 The FTC, for example, investigated allegations that Google 'unfairly 'scraped,' or misappropriated, the content of certain competing websites, passed this content off as its own, and then threatened to delist these rivals entirely from Google's search results when they protested the misappropriation of their content. ${ }^{~}{ }^{92}$ Basically, Google was stealing content from others. Google's scraping, the FTC Bureau of Competition found, was anticompetitive, violated the antitrust laws, and should be stopped. ${ }^{93}$ Google's threat "also sent a message to the broader marketplace that Google could, and would, use its monopoly power over search to extract the fruits of its rivals' innovations." "94 In an unorthodox move, the FTC closed its investigation in early 2013 after Google promised to stop scraping. ${ }^{95}$ However, despite its promise, Google reportedly continued to scrape, including the content of individual artists. As one complainant noted, "Artists need to earn a living in order to sustain creativity and licensing is paramount to this; however, this cannot happen

\footnotetext{
them are the servitors of those who have this aggregated wealth at their command.

${ }^{91} I d$.

${ }^{92}$ FTC Google Statement, supra note 15.

93 The FTC Report on Google's Business Practices, WALL ST. J. (Mar. 24, 2015), http://graphics.wsj.com/google-ftc-report [https://perma.cc/UH6Z-UKWU] (citing FED. Trade Comm'N Bureau of COMPETITION, RePORT RE GoOgle InC. (Aug. 8, 2012)) ("the natural and probable effect of Google's conduct is to diminish the incentives of [rivals] to invest in, and to develop, new and innovative content, as the companies cannot fully capture the benefits of their innovations"). There are a few caveats about this report, which the FTC released (mistakenly) under the Freedom of Information Act to the Wall Street Journal. First, only the Report's even-numbered pages were released, so the missing odd-numbered pages may have contained important qualifications. Second, other reports, including any prepared by Google, were not released. Third, although the Competition Staff recommended that the FTC sue Google, the Commissioners elected not to. Google responded to the Report's disclosure:
}

We understand that what was sent to the Wall Street Journal represents $50 \%$ of one document written by $50 \%$ of the FTC case teams. Ultimately both case teams $(100 \%)$ concluded that no action was needed on search display and ranking. Speculation about consumer or competitor harm turned out to be entirely wrong. On the other issues raised, we quickly made changes as agreed with the FTC.

${ }^{94}$ Fed. Trade Comm'N Bureau of Competition, Report Re Google InC., supra note 93, at 90 .

${ }^{95}$ FTC Google Statement, supra note 15. Then-FTC Chairman Jon Leibowitz and Commissioner Julie Brill, in a press release, expected the FTC "to enforce vigorously" Google's voluntary commitment not to scrape. Both have left the FTC. 
if Google is siphoning traffic and creating an environment where it can claim the profits from individuals' creations as its own." 96

Besides scraping, data-opolies can extract wealth from suppliers by charging them supra-competitive fees to access users. ${ }^{97}$ The Institute for Local Self-Reliance provided several examples of Amazon "retaliating against suppliers who resist its ever-mounting demands for bigger discounts and more fees," including this one:

In the early 2000s, as Amazon solidified its dominance in the book business, Bezos initiated a campaign to squeeze small publishers for better terms. Inside Amazon, the campaign was dubbed the "Gazelle Project," according to Brad Stone, after Bezos told buyers that they "should approach these small publishers the way a cheetah would pursue a sickly gazelle." One target was Melville House, a small Brooklyn-based publisher of quality fiction and nonfiction books. When Amazon approached Melville House and demanded it pay another sizeable fee, its CEO Dennis Johnson bristled at the shake-down, refused to pay, and called Publishers Weekly. A story soon appeared and the following day, Amazon removed the buy-buttons from every Melville House title on its site. At the time, Amazon represented 8 percent of the company's sales, which it couldn't afford to lose. "I paid that bribe," Johnson said, "and the books reappeared." 98

In its disputes with large publishers, Amazon also removed the buy button for Hachette's and Macmillan's books. ${ }^{99}$ Amazon said that customers who

\footnotetext{
${ }^{96}$ Samuel Gibbs, Getty Images Files Antitrust Complaint Against Google, GUARDIAN (Apr. 27, 2016), https://www.theguardian.com/technology/2016/apr/27/getty-imagesfiles-antitrust-google [https://perma.cc/5WZK-EF98]. In 2018, Google and Getty entered into a licensing agreement. See Chris O'Brien, Getty Images and Google Declare a Truce with New Image Licensing Partnership, Venture BeAt (Feb. 9, 2018, 4:33 AM), https://venturebeat.com/2018/02/09/getty-images-and-google-declare-a-truce-with-newimage-licensing-partnership/ [https://perma.cc/A4LD-FGH3].

${ }^{97}$ EZRACHI \& STUCKE, supra note 1, at 131-39.

98 Olivia LaVecchia \& Stacy Mitchell, Amazon's Stranglehold: How the COMPANY's TIGHTENING GRIP Is STIFLING COMPETITION, ERODING JOBS, AND ThreAtening Communities 23 (Institute for Local Self-Reliance Nov. 2016), https://ilsr.org/wp-content/uploads/2016/11/ILSR_AmazonReport_final.pdf [https://perma.cc/H4U8-PN59] (internal footnote omitted).

${ }^{99}$ United States v. Apple, Inc., 791 F.3d 290, 342 (2d Cir. 2015) (noting how the major publishers believed Amazon's below-cost pricing was "predatory," but understood that each publisher "was powerless to take on Amazon," as Amazon might "retaliate" against
} 
really wanted any of Hachette's 5,000 books on its platform could go "to one of our competitors." 100

Fourth, data-opolies can extract our wealth indirectly when their higher fees are passed along in the prices of the advertised goods and services. If the data-opolies faced more competitors for their advertising services, ads could cost even less - and, therefore, so might the products being advertised.

Finally, data-opolies can extract wealth from both upstream sellers and downstream consumers by facilitating or engaging in behavioral discrimination. As Virtual Competition explores, behavioral discrimination consists of convincing consumers to buy things they did not necessarily want at the highest price they are willing to pay. ${ }^{101}$

Data-opolies, in collecting data about their users, can directly engage in behavioral discrimination for the goods and services they sell. ${ }^{102}$ A data-opoly can also help its advertisers discriminate. If advertisers are at an informational disadvantage, they cannot readily identify and target those customers who are more likely to be induced to buy the product at the higher price. The advertiser thus relies on the data-opoly to identify and target these consumers, with the data-opoly getting paid whenever consumers click or see the ad. ${ }^{103}$

The data-opoly can also use its trove of personal data to price discriminate upstream - paying merchants, workers, and authors the least amount needed and well below competitive levels. ${ }^{104}$ Today many authors

insubordinate publishers, as it did against Macmillan, by removing the "buy buttons" on the Amazon site that allow customers to purchase books or by eliminating a publisher's products from its site altogether); David Streitfeld, Amazon and Hachette Resolve Dispute, N.Y. TIMES (Nov. 13, https://www.nytimes.com/2014/11/14/technology/amazon-hachette-ebook-dispute.html [https://perma.cc/YH8K-KJXJ].

${ }^{100}$ David Streitfeld, Hachette and Amazon Dig in for a Long Fight over Contract Terms, N.Y. TIMES (May 28, 2014), https://www.nytimes.com/2014/05/29/technology/amazonhachette-book-publisher-dispute.html [https://perma.cc/J58R-VRTD].

${ }^{101}$ EZRACHI \& STUCKE, supra note 1, at 85-146.

${ }^{102}$ Maurice E. Stucke \& Ariel Ezrachi, How Digital Assistants Can Harm Our Economy, Privacy, and Democracy, 32 BERKELEY TECH. L.J. 1239, 1267 (2017).

${ }^{103}$ See, e.g., SYMONS \& BASS, supra note 64, at 27 ("More recently Facebook's data has been used to build detailed psychometric profiles about their users wants, political preferences and insecurities for more intimately targeted advertising. The company offers one-to-one support to help high-paying customers to make the best use their vast database.”).

${ }^{104}$ Alex Hern, Authors Lose Out Again in Amazon Pay-Per-Page Scam, Guardian (Apr. 26, 2016, 5:00 AM), https://www.theguardian.com/technology/2016/apr/26/authors-loseout-again-in-amazon-pay-per-page-scam [https://perma.cc/236C-6C22] ("Previously, authors were paid a flat fee for every reader who downloaded their book - typically around $\$ 1.30$ (89p) per book. But after the change was introduced, they were instead paid 
rely on Amazon to publish and promote their work; they concede to onerous demands in exchange for this service. Some writers are no longer paid per copy downloaded on Kindle. ${ }^{105}$ Instead, Amazon pays the author by the number of pages that people actually read of that digital book. ${ }^{106}$ If the author cannot hold the reader's attention until the last page, the author's royalties are slashed and the data-opoly pockets the profit. So, a data-opoly can already track what we read online to transfer wealth. In the future, the data-opolies can extract even more wealth. Through their network and digital personal assistant, data-opolies can collect personal data to assess the minimum amount needed for that author to produce the e-book. Authors with a slimmer financial cushion can be more easily exploited. (Indeed, writing-related income of full-time book authors dropped thirty percent from $\$ 25,000$ in 2009 to $\$ 17,500$ in 2015. Part-time authors saw their writing income decline thirty-eight percent from $\$ 7,250$ to $\$ 4,500 .{ }^{107}$ ) But these wage reductions do not necessarily benefit readers. A data-opoly, knowing who is reading each author's work, how far the reader gets, and how loyal the reader is, can charge loyal fans higher prices (e.g., by not offering a discount).

In sum, a data-opoly's anticompetitive tactics, instead of promoting economic growth and welfare, can reduce employment, reduce quality, and hinder innovation. The discriminatory pricing can lessen the incentives of upstream suppliers and downstream customers (as they no longer capture any surplus). As data-opolies expand their platforms to digital personal assistants, the Internet of Things, and smart technologies,

six tenths of a cent for each page read, meaning that an author would have to write a 220 page book, and have every page read by every person downloading it to earn the same amount they previously got.").

${ }^{105}$ Alex Hern, Amazon Set to Pay Self-Published Authors as Little as \$0.006 Per Page Read, GUARDIAN (Jul. 2, 2015, 5:48 PM), https://www.theguardian.com/technology/2015/jul/02/amazon-pay-self-publishedauthors-per-page-read-kindle [https://perma.cc/NYP6-E9HF] (discussing authors who made their works available through Amazon's Kindle Owners Lending Library and Kindle Unlimited as of 2015).

${ }^{106}$ See Royalties In Kindle Unlimited and Kindle Owners' Lending Library, KINDLE DIRECT PUBLISHING, https://kdp.amazon.com/en_US/help/topic/G201541130 [https://perma.cc/Q4XA-FEWJ] (“A customer can read your book as many times as they like, but we will only pay you for the number of pages read the first time the customer reads them."); Anita Singh, Amazon to Pay Kindle Authors Only for Pages Read, TELEGRAPH (June 22, 2015, 5:20 http://www.telegraph.co.uk/technology/amazon/11692026/Amazons-to-pay-Kindleauthors-only-for-pages-read.html [https://perma.cc/UR3Q-YUWU].

${ }^{107}$ The Authors Guild, The Wages of Writing, KeY Findings from The Authors GUILD 2015 MEMBER SURVEY 5 (2015), https://www.authorsguild.org/wpcontent/uploads/2015/09/WagesofWriting_Final_10-22-15.pdf [https://perma.cc/BK7UJ52D]. 
the concern is that their data advantage will increase their competitive advantage and market power. ${ }^{108}$ As their capacity to extract wealth increases, more money will flow to the data-opolies.

\section{Loss of Trust}

As the prior section discusses, although a data-opoly does not charge consumers a high monetary price for its services, it nonetheless can extract consumers' and sellers' wealth. When a data-opoly pays too little (or nothing) for an individual's content or data, some individuals may forego writing posts or books, posting pictures, or producing quality music and films. This loss would represent a deadweight welfare loss.

Moreover, a data-opoly's privacy degradation can increase the deadweight welfare loss by increasing distrust. Market economies rely on trust. Fairness and trust, business and economic research shows, are highly interrelated. ${ }^{109}$ On a macro level, the empirical evidence does not identify greed as a prerequisite for a market economy. Societies with greedier residents do not necessarily have stronger economies. Instead, norms of fairness can play a far greater role than greed in supporting a market economy. As Professor Lynn Stout discussed, societal norms of fairness and prosocial behavior are both common in, and necessary for, a market economy. ${ }^{110}$ Violations of social norms of fairness decrease trust and increase retaliation.

For online markets to deliver their benefits, people must trust firms and their use of the personal data. But as technology evolves and more personal data is collected, we are increasingly aware that companies are using our personal information for their own benefit, not ours. ${ }^{111}$ Many U.K. citizens, its competition agency found, appeared unhappy with how well firms explain why they collect their personal data. ${ }^{112}$ As the agency concluded, "Consumer trust could be fragile and at risk if negative

\footnotetext{
108 See, e.g., SYMONS \& BASS, supra note 64, at 59 ("As these firms grow and increasingly encroach on one another's space, they will seek to mine even greater quantities of personal data. The risk is that with fewer but bigger platforms, possessing even greater amounts of our data, consumers and other companies will be captive in markets at the whim of a large and powerful company, able to extract greater consumer and producer surplus for their ends.").

${ }^{109}$ Maurice E. Stucke, Is Intent Relevant?, 8 J. L. ECON. \& POL'Y 801 (2012).

${ }^{110}$ Lynn Stout, Cultivating Conscience: How Good Laws Make Good People (2011).

${ }^{111}$ U.K. COMPETITION AND MARKETS AUTHORITY, THE COMMERCIAL USE OF CONSUMER DATA: REPORT ON THE CMA'S CALL FOR INFORMATION 11 (2015), https://www.gov.uk/government/uploads/system/uploads/attachment_data/file/435817/Th e_commercial_use_of_consumer_data.pdf [https://perma.cc/H92S-LJLA].

${ }^{11 \overline{2}} I d$.
} 
perceptions about new technologies or the way firms manage data take hold. We are concerned that future changes in the way that data is collected and used (such as more passive collection via the [Internet of Things]) could test how far consumers would be willing to continue to provide data." 113

If data-opolies depress privacy protections below competitive levels, some consumers will choose not "to share their data, to limit their data sharing with companies, or even to lie when providing information." 114 Consumers may forgo the data-opolies' services, which they otherwise would have used if privacy competition were robust. This loss would represent what economists call a deadweight welfare loss. In other words, as distrust increases, society overall becomes worse off.

\section{E. Data-opolies Can Impose Significant Wasteful Costs on Third Parties}

As we explore in Big Data and Competition Policy, a data-opoly can impose significant costs on rivals through myriad anticompetitive means, including (i) exclusive dealing to prevent rivals from accessing critical data, (ii) leveraging its data-advantage in a regulated market to another market, and (iii) increasing customers' switching costs. ${ }^{115}$ Dataopolies that control a key platform, like a mobile phone operating system, can cheaply exclude rivals by:

- steering users and advertisers to their own products and services to the detriment of rival sellers on the platform (and contrary to consumers' wishes);

- degrading an independent app's functionality;

- reducing traffic to an independent app by making it harder to find on its search engine or app store; or

- limiting an app's ability to deliver, target, or measure the effectiveness of ads for any app whose revenues are primarily from advertising. ${ }^{116}$

${ }^{113} I d$. at 12 .

${ }^{114} I d$. at 146.

${ }^{115}$ STUCKE \& GRUNES, supra note 1, at chapter 18.

${ }^{116}$ Id.; see also OECD Annex, supra note 49, at 5 (for exclusionary practices, the European Commission suggests "treating data as any other input: for instance, in vertical mergers, one should consider the risks of foreclosure; and, in exclusionary abuses, one should weight carefully remedies such as requirements to share data. But before any such interventions, it is crucial to identify whether data is a key element for product success, whether data is replicable or available from other sources, and how quickly data becomes outdated"). 
Data-opolies, to increase the flow of personal data, can also impose costs on companies seeking to promote privacy interests. One example, which our book, Virtual Competition, discusses, is Google kicking the privacy app, Disconnect, out of its Android app store. ${ }^{117}$ Important for our purposes is that the cost to Google was likely to be low, while the cost to Disconnect was high, as it became harder to reach Android users.

\section{F. Less Innovation in Markets Dominated by Data-opolies}

In 2004, the Supreme Court defended short-run allocative efficiency losses from monopolists with the belief that monopoly rents attract business acumen and risk-taking that produces innovation and economic growth. ${ }^{118}$ The Court assumed that companies enter a market, innovate, and compete with the expectation of monopoly rents. This is questionable. The OECD and others have found "little empirical support" for the hypothesis that large firm size or high concentration is strongly associated with a higher level of innovative activity. ${ }^{119}$ The competitive dynamics are more complex. Some monopolies and oligopolies continually innovate to maintain their competitive edge. Some, like AT\&T

${ }^{117}$ EZRACHI \& STUCKE, supra note 1, at chapter 16. Disconnect Inc. filed with the European Commission an antitrust complaint against Google. The app maker claimed Google abused its dominant position when it banned from its Google Play store Disconnect's Android app. Disconnect Mobile protects users "from invisible tracking and malvertising, malware served through ads and tracking connections." Press Release, Disconnect, We Filed an EU Antitrust Complaint against Google (June 6, 2015), https://blog.disconnect.me/our-eu-antitrust-complaint-against-google/

[https://perma.cc/Q8YL-GAGD]. As Disconnect alleged, Google abused its dominant position on Android, the Play Store, and Chrome mobile in at least two ways: "First, Google integrates its own ineffective and often misleading privacy and security 'features' into its dominant products, thereby giving itself an unfair market advantage and harming consumers in the process. Second, Google uses its market power to discriminate against Disconnect, by denying us access to the distribution and other benefits that come with being in the Play Store." Id. The complaint as of June 2018 is pending.

${ }^{118}$ Verizon Comms. Inc. v. Law Offices of Curtis V. Trinko, LLP, 540 U.S. 398, 407 (2004) ("opportunity to charge monopoly prices-at least for a short period-is what attracts 'business acumen' in the first place; it induces risk taking that produces innovation and economic growth").

119 Sanghoon Ahn, Competition, Innovation and Productivity Growth: A Review of Theory \& Evidence at 3, 5, 14-15 (OECD, Economic Working Paper No. 317, Jan. 17, 2002),

http://www.oecd.org/officialdocuments/publicdisplaydocumentpdf/?cote=ECO/WKP(20 02)3\&docLanguage $=$ En [https://perma.cc/CW4Q-8FHH]; see also JONATHAN B. BAKER, MARKET POWER IN THE U.S. ECONOMY TODAY (2017), http://equitablegrowth.org/research-analysis/market-power-in-the-u-s-economy-today/

[https://perma.cc/VR7N-EDZE]. 
and IBM, innovate but dictate for many years the progress of innovation. Some monopolies restrain innovation. ${ }^{120}$

The same is true with data-opolies. Some of their innovations can harm users. For example, their innovations, in furthering their ability to track users and collect their data, can reduce users' privacy. ${ }^{121}$ The New York Times reviewed hundreds of Facebook's patent applications. Its review revealed how "the company has considered tracking almost every aspect of its users' lives: where you are, who you spend time with, whether you're in a romantic relationship, which brands and politicians you're talking about. The company has even attempted to patent a method for predicting when your friends will die." $" 122$

Data-opolies can also hinder innovations that threaten their power or profits. Data-opolies that rely on advertising revenues may view some privacy technologies as a threat. ${ }^{123}$ Data-opolies can hinder others on their super-platform by introducing innovations that protect individuals' privacy interests. Data-opolies can determine what technology to promote. ${ }^{124}$ In determining who can access their trove of data, data-opolies can "cut off any developer who poses a competitive threat." 125

${ }^{120}$ Maurice E. Stucke, Should the Government Prosecute Monopolies?, 2009 U. ILL. L. REV. 497 (2009).

${ }^{121}$ See, e.g., Google Starts Tracking Offline Shopping-What You Buy at Stores in Person, L.A. TIMES (May 23, 2017, 2:25 PM), http://www.latimes.com/business/technology/la-fi-tn-google-ads-tracking-20170523story.html [https://perma.cc/FH2T-XBNC] (reporting how Google developed a new tool to "track how much money people spend in merchants' bricks-and-mortar stores after clicking on their digital ads").

${ }^{122}$ Sahil Chinoy, What 7 Creepy Patents Reveal About Facebook, N.Y. TIMES (June 21, 2018), https://nyti.ms/2MGqm7T [https://perma.cc/MR9C-9LYD].

${ }^{123}$ See, e.g., Facebook 2018 10-K, supra note 77, at 20:

Technologies have been developed, and will likely continue to be developed, that can block the display of our ads or block our ad measurement tools, particularly for advertising displayed on personal computers. We generate substantially all of our revenue from advertising, including revenue resulting from the display of ads on personal computers. Revenue generated from the display of ads on personal computers has been impacted by these technologies from time to time. As a result, these technologies have had an adverse effect on our financial results and, if such technologies continue to proliferate, in particular with respect to mobile platforms, our future financial results may be harmed.

124 "One criticism of Google's leading role in a standard-setting process to block ads, including on its leading browser Chrome, was "that the blacklisted ad formats generally don't apply to Google's own business, according to people who were part of the process." Douglas MacMillan, Google Will Block Spammy Ads (Just Not Many of Its Own), WALL 
Data-opolies also have innovation-chilling weapons that earlier monopolies, like Microsoft and IBM, lacked. Past monopolies were relatively less aware of what their customers and rivals were doing (or planning to do). As our book discusses, some platforms currently have a relative advantage in accessing and analysing data to discern threats well before others, including the government. ${ }^{126}$ They can "nowcast," also called "predict the present," by using search inquiries, social network postings, tweets, and other data to discern trends. Nowcasting can yield a competitive advantage and, at times, increase overall welfare in forecasting, among other things, flu epidemics, unemployment levels, number of Food Stamp recipients, or fishing harvests. ${ }^{127}$ Nowcasting also represents a potent data-based weapon not previously available for monopolies: the ability to monitor new business models in real time. The data-opoly can use its relative advantage in accessing and processing personal data, such as watching for trends in its proprietary data from

ST. J. (Feb. 14, 2018, 10:54 AM), https://www.wsj.com/articles/how-google-swayedefforts-to-block-annoying-online-ads-1518623663 [https://perma.cc/XD8X-VLPZ]; see also Samuel Gibbs, Google Turns on Default Ad Blocker Within Chrome, GUARDIAN (Feb. 15, 2018, 4:39 PM), https://www.theguardian.com/technology/2018/feb/15/googleadblocker-chrome-browser [https://perma.cc/2RDP-8HF4].

${ }^{125}$ SYMONS \& BASS, supra note 64, at 27-28 (noting how powerful platforms can reduce opportunities for innovation: "At present, some platforms do make their data available through APIs in their websites. For instance, Facebook allows developers to build on top of their platform with access to data .... However, companies will set the rules about the sharing of their own data. Facebook use their API to control who gets access to customers' social graph, Facebook Connect and Graph API. They can use this to cut off any developer who poses a competitive threat. The result is that few developers invest seriously in creating alternatives.").

${ }^{126}$ STUCKE \& GRUNES, supra note 1, at 285-87.

${ }^{127}$ See, e.g., Vasileios Lampos et al., Advances in Nowcasting Influenza-Like Illness Rates Using Search Query Logs, SCIENTIFIC REPORTS, DOI:10.1038/srep12760, Aug. 7, 2015 (applying a nonlinear query modeling approach to lower the cumulative nowcasting error in predicting influenza); Jaroslav Pavlicek \& Ladislav Kristoufek, Nowcasting Unemployment Rates with Google Searches: Evidence from the Visegrad Group Countries, 10 PLOS ONE 1, DOI:10.1371/journal.pone.0127084, May 2015, at 1-11 (showing that Google searches enhance nowcasting models of unemployment rates for the Czech Republic and Hungary but not for Poland and Slovakia); David W. Carter et al., Nowcasting Intraseasonal Recreational Fishing Harvest with Internet Search Volume, 10 PLOS ONE 1, DOI:10.1371/journal.pone.0137752, Sept. 8, 2015 (examining the potential for using nowcasting with Google Trends Internet search information to generate predictions of the recreational fishing harvest before official estimates are available); Dean Fantazzini, Nowcasting and Forecasting the Monthly Food Stamps Data in the US Using Online Search Data, 9.1 Plos ONE 1, DOI:10.1371/journal.pone.0111894, Nov. 2014, at 1-27 (proposing the use of Google data based on Internet searches about food stamps as a potential indicator to nowcast and forecast the US monthly number of individuals participating in the Supplemental Nutrition Assistance Program). 
posts on a social network, search queries, emails, and the like, to quickly identify (and squelch) nascent competitive threats. The dominant firm can acquire entrants before they become significant competitive threats or blunt the entrants' growth. It can manipulate its search engine results to make it harder to find the entrants or remove them from the app store. ${ }^{128}$

Facebook, for example, warns investors that its " $[\mathrm{p}]$ latform partners may use information shared by our users through the Facebook Platform in order to develop products or features that compete with us."129 But Facebook acquired the data-security app, Onavo, to track users' smartphone activity. This nowcasting radar

helped [Facebook] spot several potential threats, including Instagram, a photo app, which it bought in 2012; WhatsApp, a messaging service, for which it paid a stunning \$22bn in 2014; and tbh, a social-polling app, which it acquired last year [2017]. When Snapchat rebuffed it in 2013, it responded by cloning the app's most successful features. ${ }^{130}$

Thus, data-opolies with their nowcasting radar system can monitor competitive portals, in real time, where start-ups may emerge. ${ }^{131}$ They can track the nascent competitive threats shortly after they take off and

${ }^{128}$ Johannes Laitenberger, Director-General for Competition, European Comm'n, Speech at the MLex/Hogan Lovells Event in Brussels, EU Competition Law in Innovation and Digital Markets: Fairness and the Consumer Welfare Perspective (Oct. 10, 2017), http://ec.europa.eu/competition/speeches/text/sp2017_15_en.pdf [https://perma.cc/3DZ8NP9Z] (noting how "many of today's startup owners want to be acquired instead of growing to challenge the incumbents," how startup owners "are faced with a stark choice: struggling to survive or pitching their business to the online giants," and how in the last decade, "Google, Amazon, Facebook, Apple, and Microsoft made 436 acquisitions worth a total of 131 billion dollars").

129 Facebook Inc., Annual Report 15 (Form 10-K) (2012), http://www.sec.gov/Archives/edgar/data/1326801/000132680113000003/fb-

12312012x10k.htm [https://perma.cc/G33B-2E8Y].

${ }^{130}$ Smith, supra note 2.

${ }^{131}$ In complex adaptive ecosystems, such as many technology industries, innovation and dynamic forces may need competitive portals, i.e., critical inflection points when antitrust can make a key difference. When the competitive portals are open, entry, expansion, or random events during these periods of competitive opportunity can foster experimentation and significant innovation. On the other hand, a dominant firm may use its market power to close the competitive portals. Thus, abuses by data-opolies, if unchecked, may have greater negative implications beyond that immediate industry and time-frame. See StUCKE \& GRUNES, supra note 1, at 277, 281-85; ANDREW I. GAVIL \& Harry First, The Microsoft Antitrust CASES: Competition Policy for the TWENTY-FIRST CENTURY 324-25 (2014) (discussing the importance of preserving "competitive moments"). 
intercept or shoot them down long before they become visible to competition authorities and others. For start-ups, the prospect of becoming a target can chill their incentive to innovate in ways that potentially threaten a data-opoly's power.

\section{G. Social and Moral Concerns}

Historically, antitrust laws have also been concerned with how monopolies can hinder individual autonomy. Although competition policy generally is not considered a human rights issue, courts have long recognized that concentrated economic power tends to impoverish individuals of their livelihood and threaten inclusive growth that enhances human and institutional capacity. ${ }^{132}$ As courts noted long ago, when monopolies flourish, workers, who provided for their families, "will of necessity, be constrained to live in idleness and beggary." 133 Monopolies, thus, "deprive the public of the services of men in the employments and capacities in which they may be most useful to the community as well as themselves." 134 U.S. corporations "should be the carefully restrained creatures of the law and the servants of the people," but as President Cleveland warned, corporations were "fast becoming the people's masters." 135 Some may dispute such dire predictions. But even if monopolies were beneficent, opportunity and liberty remain limited.

The Sherman Act was enacted in 1890 "to put an end to great aggregations of capital because of the helplessness of the individual before

${ }^{132}$ See, e.g., Case of Monopolies, (1602) 77 Eng. Rep. 1260 (KB) 1263; Mitchel v. Reynolds, (1711) 24 Eng. Rep. $347(\mathrm{CH}) 350$ (explaining that monopolies deprive the public of useful members); Charles A. Ramsay Co. v. Associated Bill Posters, 260 U.S. 501,512 (1923) (stating that competition laws "secure equality of opportunity and . . . protect the public against evils commonly incident to destruction of competition through monopolies and combinations in restraint of trade"); Thomas J. Horton, Restoring American Antitrust's Moral Arc, 62 S.D. L. REV. 11 (2017) (reconsidering the issue of morality and antitrust from an interdisciplinary perspective that includes scholarship and learning from such diverse fields as evolutionary biology and economics, philosophy and history, and behavioral and socioeconomics); Harlan M. Blake \& William K. Jones, In Defense of Antitrust, 65 COLUM. L. REV. 377, 384 (1965) (observing that antitrust laws aimed "to expand the range of consumer choice and entrepreneurial opportunity by encouraging the formation of markets of numerous buyers and sellers, assuring ease of entry to such markets, and protecting participants - particularly small businessmenagainst exclusionary practices").

${ }_{133}$ United States v. Patterson, 55 F. 605, 611 (D. Mass. 1893).

${ }^{134}$ Alger v. Thacher, 36 Mass. 51, 54 (1837).

${ }^{135}$ Grover Cleveland, President of the U.S., Fourth Annual Message (Dec. 3, 1888), in 1 Earl W. Kintner, The Legislative History of the Federal ANTITRUSt Laws AND RELATED STATUTES 58 (1978). 
them." "136 If Congress did not heed this appeal, there would "soon be a trust for every production and a master to fix the price for every necessity of life." ${ }^{137}$ One purpose of the Sherman Act is "to prefer a system of small producers, each dependent for his success upon his own skill and character, to one in which the great mass of those engaged must accept the direction of the few." 138

Data-opolies have several weapons to hinder autonomy. They can direct (and limit) opportunities for start-ups that subsist on their superplatform. App developers subsist on Apple's and Google's popular mobile phone operating system platform. Sellers and authors subsist on Amazon's online merchant and publishing platforms. Newspapers and journalists depend on Facebook's social network platform to reach younger readers.

One example, which the European Commission's Google Shopping Case explores, is how companies depend on traffic from Google's search engine. ${ }^{139}$ Google for years has dominated the general search market. In 2004, it vertically integrated into the comparison shopping market. ${ }^{140}$ But its product (Froogle) was subpar and competed against several established players. ${ }^{141}$ Comparison shopping services, however, relied to a large extent on traffic to be competitive. ${ }^{142}$ So to disadvantage its rivals and improve its market position, Google, through its dominant search engine, redirected traffic. It began pushing its own comparison shopping service, which appeared at or near the top of the first page of its search results, while relegating the rival (and superior) comparison shopping services to the fourth or later page of its search results. ${ }^{143}$ Most people click on the first few results provided by Google's search engine. ${ }^{144}$ Very few people go to the fourth page of results. ${ }^{145}$ As a result, Google effectively diverted traffic to its own comparison shopping service, while drying up the traffic to its rivals' services. ${ }^{146}$

\footnotetext{
${ }^{136}$ United States v. Aluminum Co. of Am., 148 F.2d 416, 428 (2d Cir. 1945).

${ }^{137} 21$ CONG. REC. 2455, 2460 (1890).

${ }^{138}$ United States v. Aluminum Co. of Am., 148 F.2d at 427.

${ }^{139}$ Google Shopping Search, supra note 3, at section 7.2.2.

140 European Commission Press Release IP/17/1784, Antitrust: Commission Fines Google $€ 2.42$ Billion for Abusing Dominance as Search Engine by Giving Illegal Advantage to Own Comparison Shopping Service (June 27, 2017), http://europa.eu/rapid/press-release_IP-17-1784_en.htm [https://perma.cc/2EEK-KU96].

${ }^{141} I d$. ("Contemporary evidence from Google shows that the company was aware that Froogle's market performance was relatively poor (one internal document from 2006 stated 'Froogle simply doesn't work').").

${ }^{142} I d$. ("More traffic leads to more clicks and generates revenue.").

${ }^{143} I d$.

${ }^{144} I d$.

${ }^{145} I d$.

${ }^{146} \mathrm{Id}$.
} 
Venture capitalists now talk of "kill-zones" around the dataopolies. ${ }^{147}$ The data-opolies' annual conferences "held to announce new tools, features, and acquisitions, always 'send shock waves of fear through entrepreneurs," according to one investment firm, and "[v]enture capitalists attend to see which of their companies are going to get killed next." ${ }^{\text {A }}$ After seeing what happened to Snap, after entering Facebook's kill zone, others may fear straying into the data-opolies' sights. ${ }^{149}$ This can only chill entrepreneurism and autonomy.

But the concerns go beyond the constellation of competing services, app developers, sellers, journalists, musicians, writers, photographers, and artists dependent on the super-platform to reach users. Every individual's autonomy is at stake. In 2017, the hedge fund Jana Partners joined the California State Teachers' Retirement pension fund to demand that Apple do more to address the effects of its devices on

${ }^{147}$ The Future of Tech Startups: Into the Danger Zone, ECONOMIST (U.K. edition), June 2, 2018, at 61, http://weblogibc-co.com/wpcontent/uploads/2018/06/The_Economist_UK_Edition_-_June_02_2018.pdf

[https://perma.cc/RKH7-82WK].

${ }_{148} \mathrm{Id}$.

${ }^{149}$ Id.; Andy Meek, Snapchat's New Feature Focuses on Privacy, So Facebook Probably Won't Steal This, YAHOO FINANCE (June 14, 2018), https://finance.yahoo.com/news/snapchat-feature-focuses-privacy-facebook-probablywon-t-202229252.html [https://perma.cc/M8UK-KE53] ("The dynamic between the two companies, of course, has seen Facebook - after unsuccessfully trying to buy Snap copy and repurpose everything of its smaller rival that it possibly can, like Stories and ridiculous camera lenses.”). As Snap warned its investors,

Certain competitors, including Apple, Facebook, and Google, could use strong or dominant positions in one or more markets to gain competitive advantages against us in areas where we operate, including by:

- integrating competing social media platforms or features into products they control such as search engines, web browsers, or mobile device operating systems;

- making acquisitions for similar or complementary products or services; or

- impeding Snapchat's accessibility and usability by modifying existing hardware and software on which the Snapchat application operates.

As a result, our competitors may acquire and engage users at the expense of our user growth or engagement, which may seriously harm our business.

Snap Inc., Annual Report 15 (Form 10-K) (Feb. 21, 2018), https://otp.tools.investis.com/clients/us/snap_inc/SEC/secshow.aspx?FilingId $=12569789 \& \mathrm{Cik}=0001564408 \&$ Type $=\mathrm{PDF} \&$ hasPdf $=1$ [https://perma.cc/NX5D-58EC]. 
children. ${ }^{150}$ As The Economist noted, "You know you are in trouble if a Wall Street firm is lecturing you about morality." 151 The concern is that the data-opolies' products are purposefully addictive and thereby eroding individuals' ability to make free choices.

It is worth noting an interesting counterargument based on the interplay between monopoly power and competition. On the one hand, in monopolized markets, consumers have fewer competitive options. So, arguably, there is less need to addict them. On the other hand, dataopolies, like Facebook and Google, even without significant rivals, can increase profits by increasing our engagement with their products. ${ }^{152}$

This distinguishes data-opolies from past monopolies. Gillette, before losing business to online rivals, controlled over seventy percent of the U.S. men's razors business. ${ }^{153}$ While many people shaved daily, there were limits in consumption. Gillette could not induce users to reach for its razor every few hours. But Facebook, even without significant rivals, benefits financially when users are more engaged with its social network platform. Facebook obtains more personal data. Engaged users post more content, which attracts others to its social network. There are more opportunities to target users with ads. Basically, in repeatedly targeting

150 Letter from JANA Partners and CalSTRS to Apple Inc. (Jan. 6, 2018), https://thinkdifferentlyaboutkids.com/ [https://perma.cc/3K82-6H2X]; Robert G. Eccles, Why an Activist Hedge Fund Cares Whether Apple's Devices Are Bad for Kids, HARV. BUS. REV. (Jan. 16, 2018), https://hbr.org/2018/01/why-an-activist-hedge-fund-careswhether-apples-devices-are-bad-for-kids [https://perma.cc/MM9B-JH7Z].

${ }^{151}$ Smith, supra note 2.

152 Tim Wu, Blind Spot: The Attention Economy and the Law, ANTITRUST L.J. (forthcoming 2018), https://ssrn.com/abstract=2941094 [https://perma.cc/3KQ2-8MSQ]; see also OECD Big Data Report, supra note 43, at 12-13:

Attention platforms, such as search engines or social networks, typically provide a set of 'free' services that are subsidised by advertising sold on a 'per-click' basis. This way, instead of paying a monetary price for the service, consumers pay with their attention, by having paid results, organic results interspaced with publicity or by being required to watch an advertisement before gaining access to a content video. Arguably, consumers also pay by submitting their data, either indirectly - through the website recording clicks for online searches or shopping - or directly - through entering personal data into an online form. The attention platform then uses the consumer's private data to improve the quality of the services and to better target advertisements, allowing the platform to attract new consumers and to charge a higher cost-per-click to advertisers.

${ }^{153}$ Sharon Terlep, Gillette, Bleeding Market Share, Cuts Prices of Razors, WaLl ST. J. (Apr. 4, 2017), https://www.wsj.com/articles/gillette-bleeding-market-share-cuts-pricesof-razors-1491303601 [https://perma.cc/U9GD-JWHU]. 
people with ads, data-opolies can generate and then fulfill demand. ${ }^{154}$ As Facebook tells investors, "We have over 184 million people using Facebook every day in the U.S., which is considerably more than [the] Super Bowl every day on mobile alone." ${ }^{\prime 155}$ Facebook also attracts six million advertisers. ${ }^{156}$ Thus, if increasing users' engagement increases revenues and profits, data-opolies have the incentive to exploit behavioral biases and imperfect willpower to increase users' addiction to their platform - whether watching YouTube videos or posting on Instagram. ${ }^{157}$ Some of the harms from this addiction on adults' and children's development are coming to light, including higher rates of depression and less satisfaction with nearly every aspect of their lives. ${ }^{158}$

Moreover, traditional privacy concerns arise when a significant volume and variety of personal data are concentrated in the hands of a few data-opolies. ${ }^{159}$ Our autonomy is impinged with the resulting decline in:

- associational privacy (in our choices of the persons, groups, or causes with which we wish to associate),

- physical privacy (in not having our movements tracked),

${ }^{154}$ Facebook Inc., Fourth Quarter and Full Year 2017 Results Conference Call (2018), at 17, https://s21.q4cdn.com/399680738/files/doc_financials/2017/Q4/Q4-17-Earnings-calltranscript.pdf [https://perma.cc/N3U2-CH22].

${ }^{155} I d$. at 12 . The trends in the number of users affect Facebook's "revenue and financial results" by influencing the number of ads it can show, and the value of its ads to marketers. Facebook 2018 10-K, supra note 77, at 35.

${ }^{156}$ Facebook Inc., Fourth Quarter and Full Year 2017 Results Conference Call (2018), at 17, https://s21.q4cdn.com/399680738/files/doc_financials/2017/Q4/Q4-17-Earnings-calltranscript.pdf [https://perma.cc/N3U2-CH22].

${ }^{157}$ Betsy Morris, The New Tech Avengers, WALL ST. J. (June 29, 2018, 8:10 PM), https://www.wsj.com/articles/the-new-tech-avengers-1530285064

[https://perma.cc/4WQZ-ABC3]; Levi Sumagaysay, Former Google, Facebook Employees Step Up Battle Against Tech Addiction, MERcury News (Feb. 5, 2018, 3:01

PM), https://www.mercurynews.com/2018/02/05/former-google-facebook-employeesstep-up-battle-against-tech-addiction/ [https://perma.cc/ELN3-SXT6]; Nellie Bowles, Early Facebook and Google Employees Form Coalition to Fight What They Built, N.Y. TIMES (Feb. 4, 2018), https://www.nytimes.com/2018/02/04/technology/early-facebookgoogle-employees-fight-tech.html [https://perma.cc/GF5U-SG8U].

${ }^{158}$ Letter from Campaign for a Commercial-Free Childhood, to Mark Zuckerberg, CEO, Facebook (Jan. 30, 2018), http://www.commercialfreechildhood.org/sites/default/files/develgenerate/gaw/FBMessengerKids.pdf [https://perma.cc/8ZZJ-PSZM]; David Ginsberg, Hard Questions: Is Spending Time on Social Media Bad for Us?, FACEBOOK (Dec. 15, 2017), https://newsroom.fb.com/news/2017/12/hard-questions-is-spending-time-onsocial-media-bad-for-us/ [https://perma.cc/34W9-98UG].

${ }^{159}$ Sofia Grafanaki, Autonomy Challenges in the Age of Big Data, 27 FordHAM InTELL. PRop. MEdia \& ENT. L. J. 803 (2017). 
- informational privacy (in choosing with whom we wish to disclose our personal information),

- decisional privacy (in not having a company intrude in our personal decisions), and

- intellectual privacy (namely, the freedom to explore topics and issues without a company monitoring us). ${ }^{160}$

\section{H. Political Concerns of Data-opolies}

Economic power often translates into political power. Powerful domestic producers, besides swaying the government to erect protectionist measures, can also dampen the democratic process. ${ }^{161}$ As Justice Douglas noted in 1948 and the courts later repeated:

Power that controls the economy should be in the hands of elected representatives of the people, not in the hands of an industrial oligarchy. Industrial power should be decentralized. It should be scattered into many hands so that the fortunes of the people will not be dependent on the whim or caprice, the political prejudices, the emotional stability of a few self-appointed men. The fact that they are not vicious men but respectable and social minded is irrelevant. That is the philosophy and the command of the Sherman Act. It is founded on a theory of hostility to the concentration in private hands of power so great that only a government of the people should have it. ${ }^{162}$

Once power and wealth are concentrated, social policies are directed to preserve the status quo. Invariably this concentration in

\footnotetext{
${ }^{160}$ Anita L. Allen, Symposium: Privacy Jurisprudence as an Instrument of Social Change First Amendment Privacy and the Battle for Progressively Liberal Social Change, 14 U. PA. J. CONST. L. 885, 889 (2012) (providing different conceptions of privacy).

${ }^{161}$ See, e.g., AKHIL ReEd AMAR, AMERICA's CONSTITUTION: A BiograpHy 412 (2005) (discussing how the direct election of U.S. Senators was to counter the undue effects of large corporations, monopolies, trusts, and other special-interest groups in the Senate election process); Thomas J. Horton, The Coming Extinction of Homo Economicus and the Eclipse of the Chicago School of Antitrust: Applying Evolutionary Biology to Structural and Behavioral Antitrust Analyses, 42 LoY. U. CHI. L.J. 469, 503-04 (2011); Frank Maier-Rigaud, On the Normative Foundations of Competition Law: Efficiency, Political Freedom and the Freedom to Compete, in THE GoALs OF COMPETITION LAW 132 (Daniel Zimmer ed., 2012).

162 United States v. Columbia Steel Co., 334 U.S. 495, 536 (1948) (Douglas, J., dissenting); see also United States v. Vandebrake, 771 F. Supp. 2d 961, 1000-01 (N.D. Iowa 2011); United States v. Am. Tel. \& Tel. Co., 552 F. Supp. 131, 164 (D.D.C. 1982).
} 
economic power threatens democratic ideals and leads to corporatism. ${ }^{163}$ Thus, antitrust's underlying political concern is that private economic power, like all absolute power, is subject to abuse and injurious to public welfare. Such power must be decentralized to protect a free society from its abuse. Competitively structured markets diffuse private power and discipline economic decision-making; and antitrust policy is critical in preserving competitive markets.

Data-opolies raise similar concerns about crony capitalism and lobbying to help maintain their monopoly power. First, data-opolies have every financial incentive to maintain (and increase) their profits. Google, Apple, Facebook, Amazon, and Microsoft had the largest absolute increase in market capitalization between 2009 and $2017 .{ }^{164}$ As of June 2018, they were the largest U.S. public companies by market capitalization. ${ }^{165}$ In 2017, Google "spent over \$18 million lobbying politicians," which was "the first time a technology company has spent the most on lobbying costs in at least two decades."166 Likewise, compared to 2016 levels, Facebook increased its lobbying spending by nearly $\$ 3$ million ( $\$ 11.5$ million), Apple by $\$ 2.3$ million ( $\$ 7$ million), and Amazon by nearly $\$ 2$ million ( $\$ 12.8$ million). ${ }^{167}$

The lobbying can be direct. For example, the week after the public learned that the FTC was investigating Google for monopolistic abuses, the company hired twelve additional lobbying firms and increased its lobbying expenses by eighty-eight percent, becoming among "the top 10

\footnotetext{
${ }^{163}$ See, e.g., Ford Motor Co. v. United States, 405 U.S. 562, 569 n.5 (1972) (quoting Senator Kefauver on the "evil" of increasing concentration "with more and more corporations purchasing out their competitors" such that when "people lose their economic freedom, they lose their political freedom"); Spencer Weber Waller, Antitrust and Democracy: Democracy in Antitrust (Dec. 11, 2017), https://ssrn.com/abstract=3086260 [https://perma.cc/CVH7-GSE6]; WALTER ADAMS \& JAMES W. BROCK, THE BIGNESS COMPLEX 305-6 (2004).

${ }^{164}$ PWC, Global Top 100 COMPANiEs By MARKET CAPITALisation 21 (Mar. 31, 2017), https://www.pwc.com/gx/en/audit-services/assets/pdf/global-top-100-companies-2017final.pdf [https://perma.cc/GGL6-F2W2].

165 The Largest Companies by Market Capitalization Today, Symbol SuRfing, http://www.symbolsurfing.com/largest-companies-by-market-capitalization [https://perma.cc/6SA8-KKB2]; see also Jeff Desjardins, Chart: The Largest Companies by Market Cap over 15 Years, Visual CAPITAlist (Aug. 12, 2016, 11:18 AM), https://www.visualcapitalist.com/chart-largest-companies-market-cap-15-years/ [https://perma.cc/K7B6-UEKR].

${ }^{166}$ Alana Abramson, Google Spent Millions More Than its Rivals Lobbying Politicians Last Year, TIME (Jan. 24, 2018), http://time.com/5116226/google-lobbying-2017/ [https://perma.cc/9D98-Q668].

${ }^{167} \mathrm{Id}$.
} 
of spenders seeking to influence the federal government." ${ }^{\text {168 }}$ During this time, Google "had a flurry of meetings with top officials at the White House and Federal Trade Commission." 169 What was discussed is not public. But the frequency of these meetings shows one firm's unequaled access to the highest levels of the Executive Branch and the opportunities to align governmental policies with corporate interests. ${ }^{170}$ Thus, depending on one's view of political capture, it was (or was not) surprising when the FTC Commissioners, contrary to the recommendations of the legal staff, closed its Google investigation.

Data-opolies also can lobby indirectly. They can influence the debate through the funding of articles, academic initiatives, and think tanks. ${ }^{171}$ Data-opolies and their executives can voice their displeasure (and possibility of withholding their funding) to groups that question their abuses, power, or policy recommendations. ${ }^{172}$ Data-opolies can seek to influence the privacy debate by downplaying privacy and advertising regulations, which threaten their advertising-dependent economic model. In contrast to the E.U.'s General Data Protection Regulation and forthcoming ePrivacy regulation, which potentially threaten the advertising-dependent data-opolies, and California's Consumer Privacy

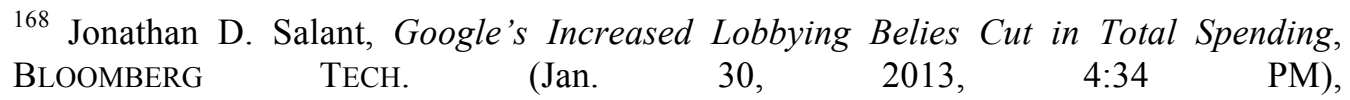
https://www.bloomberg.com/news/articles/2013-01-30/google-s-increased-lobbyingbelies-cut-in-total-spending [https://perma.cc/AJ65-KNXT].

${ }^{169}$ Brody Mullins, Google Makes Most of Close Ties to White House, WALL St. J. (Mar. 24, 2015, 9:24 PM), https://www.wsj.com/articles/google-makes-most-of-close-ties-towhite-house-1427242076 [https://perma.cc/E9D8-4BAD].

${ }^{170}$ Evidence suggests that political access is of significant value to corporations. See generally Jeffrey R. Brown \& Jiekun Huang, All The President's Friends: Political Access and Firm Value (Nat'l Bureau of Econ. Research, Working Paper No. 23356, 2017), http://www.nber.org/papers/w23356 [https://perma.cc/D624-2QLL]. Using data on White House visitors from 2009 through 2015, the study found that corporate executives' meetings with key policymakers were associated with positive abnormal stock returns, and that "following meetings with federal government officials, firms receive more government contracts and are more likely to receive regulatory relief (as measured by the tone of regulatory news)."

${ }^{171}$ Brody Mullins, Paying Professors: Inside Google's Academic Influence Campaign, WALL ST. J. (July 14, 2017, 9:14 AM), https://www.wsj.com/articles/paying-professorsinside-googles-academic-influence-campaign-1499785286 [https://perma.cc/RPR5JQQU].

${ }^{172}$ Kenneth P. Vogel, New America, a Google-Funded Think Tank, Faces Backlash for Firing a Google Critic, N.Y. TIMES (Sept. 1, 2017), https://www.nytimes.com/2017/09/01/us/politics/anne-marie-slaughter-new-americagoogle.html [https://perma.cc/AP7G-DC9W]; Kenneth P. Vogel, Google Critic Ousted from Think Tank Funded by the Tech Giant, N.Y. TIMES (Aug. 30, 2017), https://www.nytimes.com/2017/08/30/us/politics/eric-schmidt-google-new-america.html [https://perma.cc/RCV5-ES9S]. 
Act of 2018, Congress has not enacted any significant privacy protections. Data-opolies likely will lobby against significant privacy protections, including providing users a property right (or greater legal rights) over their data and enhancing data portability (to the extent it threatens their power). ${ }^{173}$

Unlike earlier monopolies, data-opolies, given how they interact with individuals, possess a far more powerful tool: their ability to affect the public debate and public's perception of right and wrong. Many people now receive their news from social media platforms. In 2017, Facebook outstripped "all other social media sites as a source of news," with fortyfive percent of Americans receiving news on Facebook. ${ }^{174}$ YouTube was the second most common social media site for news. ${ }^{175}$

But the news is not passively transmitted and consumed. Dataopolies can affect how we feel and think. One example is Facebook's emotional contagion study, where it manipulated 689,003 users' emotions. ${ }^{176}$ Data-opolies, with the development of personal digital

${ }^{173}$ SYMONS \& BASS, supra note 64, at 32 (noting that part of the "difficulty for making personal data open is the lack of [existing] legal, technical or economic norms that would allow people to both collect, control and share their own data. If this were possible, then people might be able to share their data for specific projects or causes, or share it under specific conditions"); Kieren McCarthy, Google Lobbies Hard to Derail New US Privacy Laws - Using Dodgy Stats: Expect to Hear A Lot About Censorship and Criminals in the Next Few Months, Register (Mar. 26, 2018, 8:52 PM), https://www.theregister.co.uk/2018/03/26/as_tech_criticism_grows_google_lobbies_to_u ndercut_new_privacy_laws/ [https://perma.cc/J3H9-ZEWJ]; Daisuke Wakabayashi, California Passes Sweeping Law to Protect Online Privacy, N.Y. TIMES (June 28, 2018), https://www.nytimes.com/2018/06/28/technology/california-online-privacy-law.html [https://perma.cc/8YDQ-RPUD] (Google and Facebook, among others, each contributed $\$ 200,000$ to a committee opposing California's proposed ballot measure on privacy, with lobbyists estimating that businesses would spend $\$ 100$ million to campaign against it before the November election).

${ }^{174}$ Elisa Shearer \& Jeffrey Gottfried, News Use Across Social Media Platforms 2017, PEW RES. CTR. (Sept. 7, 2017), http://www.journalism.org/2017/09/07/news-use-acrosssocial-media-platforms-2017/ [https://perma.cc/8E2N-EKQH].

${ }^{175} \mathrm{Id}$

${ }^{176}$ Facebook sought to examine "emotional contagion," whereby people transfer positive and negative moods and emotions to others. Adam D. I. Kramer, Jamie E. Guillory \& Jeffrey T. Hancock, Experimental Evidence of Massive-Scale Emotional Contagion Through Social Networks, 111 PROC. NAT'L ACAD. SCI. 8788 (2014). This was the "first experimental evidence for massive-scale emotional contagion via social networks." Id. at 8789. People, when posting on Facebook, frequently express positive or negative emotions. Their friends later see these posts via Facebook's "News Feed" product. Facebook uses a ranking algorithm that continually tests which content is shown or omitted in the News Feed. The aim is to show particular Facebook users "the content they will find most relevant and engaging." Id. at 8788. Facebook, as part of the study, intentionally manipulated its News Feed algorithm. Some users received less positive content. Others received less negative emotional content. When Facebook surreptitiously 
assistants, can be even more active in shaping our thoughts. In 2017, Google announced it is incorporating artificial intelligence (AI) into its Gmail service, used by over a billion people, "for features such as suggesting responses to messages." "177 Similarly, Facebook is using AI, as part of its personal assistant technology, to provide suggestions to users based on their private conversations. ${ }^{178}$ Among other things, data-opolies may suggest books, articles, photos, or posts users may wish to share.

These practices bring with them many risks, one of which is bias. Data-opolies may simply cater to users who prefer news that supports their preexisting beliefs. One 2015 study of over ten million Facebook users "observed substantial polarization among hard [news] content shared by users, with the most frequently shared links clearly aligned with largely liberal or conservative populations." ${ }^{179}$ After the algorithm ranked the stories ${ }^{180}$ Facebook users were slightly less likely to see politically different viewpoints. ${ }^{181}$ Individual choice, however, further substantially limited users' exposure to ideologically cross-cutting content. ${ }^{182}$ Facebook has sought to patent technologies to infer personality traits from users' posts and messages: "It describes judging your degree of extroversion, openness or emotional stability, then using those characteristics to select which news stories or ads to display." "

reduced friends' positive content in the News Feed for one week, the users were less positive: "a larger percentage of words in the users' status updates were negative and a smaller percentage were positive." $I d$. at 8789 . When Facebook surreptitiously reduced their friends' negative content in the News Feed, the Facebook users were less negative themselves. People who were exposed to fewer emotional posts (either positive or negative) in their News Feed "were less expressive overall on the following days." Id. at 8790. In manipulating the News Feed, Facebook could influence users' moods.

177 Google Assistant Coming to iPhones; Will Take on Siri, WION (May 18, 2017, 1:11PM), https://www.wionews.com/science-tech/google-assistant-coming-to-iphoneswill-take-on-siri-15719 [https://perma.cc/3GYZ-QLFT]; Karissa Bell, Gmail Can Use Google's AI to Write Replies for You, MASHABLE (May 17, 2017), http://mashable.com/2017/05/17/gmail-smart-replies/\#wbmaFUiXlOqK

[https://perma.cc/FZG8-W9PF].

${ }_{178}$ Kurt Wagner, Facebook Is Using AI in Private Messages to Suggest an Uber or Remind You to Pay a Friend, ReCODE (Apr. 6, 2017), https://www.recode.net/2017/4/6/15203526/facebook-messenger-m-artificialintelligence-ai-bots [https://perma.cc/VPR2-8JDE].

179 Eytan Bakshy et al., Exposure to Ideologically Diverse News and Opinion on Facebook, 348 SCIENCE 1130, 1130 (2015).

${ }^{180}$ The order in "which users see stories in the News Feed depends on many factors, including how often the viewer visits Facebook, how much they interact with certain friends, and how often users have clicked on links to certain websites in News Feed in the past." Id. at 1131.

${ }^{181} I d$.

${ }^{182} \mathrm{Id}$.

${ }^{183}$ Chinoy, supra note 122. 
necessarily provide an ideologically diverse news stream. ${ }^{184}$ Instead, in filtering the information we receive based on our preferences, a data-opoly can reduce the viewpoints we receive, thereby leading to "echo chambers" and "filter bubbles." 185

A second risk is censorship, whereby a data-opoly, through its platform, controls or blocks the content that users can access. ${ }^{186}$ The dataopoly can enforce governmental censorship of information with particular religious, political, and sexual orientations. ${ }^{187}$ For example, in 2017 Apple removed several popular apps that enabled users to evade government censorship from its app store in China. ${ }^{188}$ Additionally, the data-opoly can self-censor as to what content is appropriate. Facebook is currently grappling with this issue and, in 2017, asked users for input on several questions, including:

- How aggressively should social media companies monitor and remove controversial posts and images from their platforms?

- Who gets to decide what is controversial, especially in a global community with a multitude of cultural norms?

\footnotetext{
${ }^{184}$ Due to pervasive psychological confirmation biases, users are unlikely to want to hear both the conservative and liberal slant for every news story. See Andrea M. Matwyshyn, The Law of the Zebra, 28 BERKELEY TECH. L.J. 155, 210 (2013) ("Particularly when the topic is an emotionally-charged or threatening issue, confirmation bias is a common occurrence.").

${ }^{185}$ OECD Background Note, supra note 48, at 42; see also OECD, Algorithms and Collusion: Note by the European Commission, at 2, DAF/COMP/WD(2017)12 (June 14, 2017) (noting that when it comes to recommending newspaper articles, personalization can limit the range of views that consumers are exposed to, which is the so-called "filter bubble" or "echo chamber" phenomenon).

${ }^{186}$ OECD Background Note, supra note 48, at 43; Greg Ip, How Google and Facebook Are Monopolizing Ideas, WALL ST. J. (July 4, 2018, 10:05 AM), https://www.wsj.com/articles/how-google-and-facebook-are-monopolizing-ideas-

1530713153 [https://perma.cc/8DUP-W3FR]; David Dayen, Google Is So Big, It Is Now Shaping Policy to Combat the Opioid Epidemic. And It's Screwing It Up, INTERCEPT (Oct. 17, 2017), https://theintercept.com/2017/10/17/google-search-drug-use-opioidepidemic/ [https://perma.cc/C99D-5XTQ].

${ }^{187}$ Paul Mozur, China Presses Its Internet Censorship Efforts Across the Globe, N.Y. TIMES (Mar. 2, 2018), https://www.nytimes.com/2018/03/02/technology/chinatechnology-censorship-borders-expansion.html [https://perma.cc/ZH6T-E487].

${ }^{188}$ Paul Mozur, Apple Removes Apps from China Store That Help Internet Users Evade Censorship, N.Y. TIMES (July 30, 2017),
} https://www.nytimes.com/2017/07/30/technology/china-apple-censorhip.html [https://perma.cc/3JR4-2RMT]. 
- Who gets to define what's false news - and what's simply controversial political speech? ${ }^{189}$

Ultimately the answers will come not from users, but from Facebook and other data-opolies. In 2018, Facebook posted its community standards, which gave it wide discretion. For example, at times, Facebook "will allow content that might otherwise violate our standards if we feel that it is newsworthy, significant, or important to the public interest. We do this only after weighing the public interest value of the content against the risk of real-world harm." 190 Showing how subjective (or fickle) this can be, Instagram, in 2018, deleted a video by the non-profit news outlet ProPublica, identifying members of a white violent supremacist group because the video supposedly violated its terms of service. As ProPublica's editor-in-chief remarked, "A platform that censors journalism because it cannot distinguish between racist rants and investigative reporting clearly needs to review its procedures."

A third risk is manipulation. ${ }^{192}$ One illustration is the use of the data-opoly's platform to manipulate elections. We are learning more how the Russian government used Facebook, Google, and Twitter to influence the 2016 U.S. Presidential elections. The Special Counsel, in one indictment, alleged how Russian groups, "through fraud and deceit, created hundreds of social media accounts and used them to develop certain fictitious U.S. personas into 'leader[s] of public opinion' in the United States." 193 Their strategic goal was "to sow discord in the U.S. political system, including the 2016 U.S. presidential election." 194

To sow discord in the U.S. political system, the Russians relied on, among other things, the data-opolies' social media platforms such as Google's YouTube, Facebook's social network, and Instagram. ${ }^{195}$ By 2016, the size of the online followers of many of their controlled online groups had grown to hundreds of thousands of online followers. The

189 Facebook, Hard Questions, FACEBOOK (June 15, 2017), https://newsroom.fb.com/news/2017/06/hard-questions/ [https://perma.cc/3BHV-88VU].

${ }_{190} \quad$ Facebook, Community Standards, https://m.facebook.com/communitystandards\#attacks-on-public-figures [https://perma.cc/DN4J-T8N2].

${ }^{*}{ }^{191}$ Rob Price, Instagram Deleted a Video by a News Outlet That Identified Members of a White Supremacist Group, Bus. INSIDER (June 21, 2018, 8:59 PM), $\mathrm{http}: / / \mathrm{www}$.businessinsider.com/instagram-deletes-propublica-video-white-supremacistgroup-2018-6 [https://perma.cc/SJ4V-X9XP].

${ }^{192}$ OECD Background Note, supra note 48.

193 Indictment at 932 , U.S. v. Internet Research Agency, Case 1:18-cr-00032-DLF

(D.D.C. Feb. 16, 2018).

${ }^{194} I d$. at 96.

${ }^{195} \mathrm{Id}$. at 10. 
Russians spent thousands of dollars every month advertising their groups on social media sites. Pretending to be grass-roots organizations, they also used the social media sites to stage U.S. political rallies. The data-opolies provided an effective arsenal for the Russian's proclaimed "information warfare against the United States of America," with the stated goal of "spread[ing] distrust towards the candidates and the political system in general." "196 According to Facebook's estimates, over 126 million Facebook users saw some of these Russian groups' propaganda. ${ }^{197}$ The Russians generated over 131,000 tweets and uploaded over 1,000 videos on Google's YouTube service. ${ }^{198}$

If Russia can manipulate the U.S. elections through its postings, just consider the data-opolies' power to manipulate elections. Jonathan Zittrain warned of the super-platform's potential ability to predict political views, identify party affiliation, and engage in targeted campaigning to mobilize distinct groups of voters to take action. ${ }^{199}$ Robert Epstein, likewise, illustrated how Google, in manipulating the rankings of its search results, could shift the voting preferences of undecided voters by " 20 percent or more - up to 80 percent in some demographic groupswith virtually no one knowing they are being manipulated." ${ }^{200}$ Dataopolies can promote stories that further their particular business or political interests, instead of stories that are relevant or high-quality.

So unlike earlier media monopolies, data-opolies can interact directly with users, collect data about them, and better target them. With more levers to affect public opinion, the risk of abuse increases. As one report aptly summarized:

The increasing value of greater data supply would lead to a consolidation in the number of platforms people use to

\footnotetext{
${ }^{196} I d$.

${ }^{197}$ Mike Isaac \& Daisuke Wakabayashi, Russian Influence Reached 126 Million Through Facebook Alone, N.Y. TIMES (Oct. 30, 2017), https://www.nytimes.com/2017/10/30/technology/facebook-google-russia.html [https://perma.cc/D2CX-4RMC]; Garrett Graff, Inside the Mueller Indictment: a Russian Novel of Intrigue, WIRED (Feb. 20, 2018), https://www.wired.com/story/inside-themueller-indictment-a-russian-novel-of-intrigue/ [https://perma.cc/EF7V-QY35].

${ }^{198}$ Isaac \& Wakabayashi, supra note 197; Graff, supra note 197.

199 Jonathan Zittrain, Facebook Could Decide an Election Without Anyone Ever Finding Out: The Scary Future of Digital Gerrymandering-and How to Prevent It, NEW REPUBLIC (June 1, 2014), https://newrepublic.com/article/117878/information-fiduciarysolution-facebook-digital-gerrymandering [https://perma.cc/HHU8-8HF8].

${ }^{200}$ Robert Epstein, How Google Could Rig the 2016 Election: Google Has the Ability to Drive Millions of Votes to a Candidate with No One the Wiser, POLITICO (Aug. 19, 2015), http://www.politico.com/magazine/story/2015/08/how-google-could-rig-the-2016election-121548 [https://perma.cc/ZW9F-N9TY].
} 
conduct their online lives. Network effects would enable internet giants to eliminate or acquire competition, making them even bigger, to a massively greater extent than we witness today. The handful of large platforms would begin to provide a comprehensive life management service, from shopping, banking, transport, work, health and social networking. All of these activities would be dataintensive, running on insights drawn from historic data all the while collecting evermore data.

The vastness of the personal data universe, and the sophistication of new technologies, would make regulation difficult. There would be considerable scope for personal data to be used to manipulate people for malign purposes. It could undermine democracy, a fair economy and social cohesion. People may be excluded from banking services, insurance, housing, jobs and even social activities on the basis of their data points. A sense of perpetual digital surveillance would cloak society, compromising any sense of freedom. ${ }^{201}$

\section{Data-opolies CAn Be More Durable}

While data-opolies raise many potential harms, we would be less concerned if their power were transient. But several factors can make dataopolies more durable than prior monopolies.

First, the nature of these data-driven industries often involves high up-front sunk costs and close-to-zero marginal costs. ${ }^{202}$ This cost structure can facilitate market concentration of Big Data in the hands of a few players. ${ }^{203}$

Second, several network effects help protect data-opolies' power. ${ }^{204}$ Firms still compete in markets with network effects. But these markets, given the network effects, can tip towards one or two products or

\footnotetext{
${ }^{201}$ SYMONS \& BASS, supra note 64 , at 34.

${ }^{202}$ OECD Big Data Report, supra note 43, at 11 ("The information technologies required to store and process the data can be very costly, involving vast data centres, servers, dataanalytical software, internet connections with advanced firewalls and expensive human resources, such as computer scientists and programmers. Once the system is fully operational, the incremental data can 'train' and improve the algorithms at a low cost (thereby also the product or service quality).").

${ }^{203} \mathrm{Id}$.

${ }^{204}$ See Google Shopping Search, supra note 3, Фๆ 285-305 (discussing barriers to general search services); STUCKE \& GRUNES, supra note 1, at 162-200 (discussing several different data-driven network effects).
} 
platforms. As the D.C. Circuit stated in the Microsoft antitrust case, as a product or standard increases in popularity, it trends towards dominance precisely "because the utility that a user derives from consumption of the good increases with the number of other agents consuming the good."205 Once the market tips and dominance is achieved, it is harder for smaller competitors to scale up to dethrone a data-opoly: "threats come largely from outside the dominated market, because the degree of dominance of such a market tends to become so extreme." 206

A result of these data-driven network effects is to limit one's incentives to switch to better alternatives, if any exist. ${ }^{207}$ Users, for example, may have been angry with Facebook after the Cambridge Analytica scandal. But they could not unilaterally switch to another social network if their friends remained on Facebook. Thus, the \#DeleteFacebook campaign fizzled. ${ }^{208}$ Users may prefer DuckDuckGo's privacy policies but remain with the dominant search engine, which, benefitting from network effects, offers better results. Drivers might prefer a more privacy-focused navigation app but stick with Google's dominant Maps or Waze apps, which, again benefitting from network effects, has better traffic information. As the OECD observed, "The dominant platform may not do anything that can be properly qualified as anticompetitive, and yet the feedback loop can reinforce dominance and prevent rival platforms from gaining customers."209

Third, innovation, rather than disrupting the status quo, may simply reinforce user lock-in and the data-opolies' power. ${ }^{210}$ Data, which conceivably could benefit multiple constituencies, including non-profit and governmental entities, now benefit primarily one party, or group of market participants (such as advertisers). The data-opoly can dictate who

\footnotetext{
${ }^{205}$ United States v. Microsoft Corp., 253 F.3d 34, 49 (D.C. Cir. 2001).

${ }^{206}$ Novell, Inc. v. Microsoft Corp., 505 F.3d 302, 308 (4th Cir. 2007); see also Microsoft, 253 F.3d at 49 ("Once a product or standard achieves wide acceptance, it becomes more or less entrenched. Competition in such industries is 'for the field' rather than 'within the field."').

${ }^{207}$ OECD Big Data Report, supra note 43, at 10-11.

208 Max A. Cherney, Facebook Earnings Beat Despite Backlash, Shares Surge, MARKETWATCH (Apr. 26, 2018), https://www.marketwatch.com/story/facebookearnings-beat-estimates-amid-data-privacy-concerns-2018-04-25

[https://perma.cc/2AXZ-K33T].

${ }^{209}$ OECD Big Data Report, supra note 43, at 10-11.

${ }^{210}$ Karolina Safarzyńska \& Jeroen C.J.M. van den Bergh, Evolutionary Models in Economics: A Survey of Methods and Building Blocks, 20(3) J. EvOlutionary ECON. 329 (Jan. 2010), DOI:10.1007/s00191-009-0153-9 (“once a certain technology becomes dominant, subsequent adoptions will most likely be of the same type enhancing its leading position").
} 
is granted access to the data and for what purpose, and thereby influence the nature of innovation.

Fourth, the harm from a data-opoly is often less salient. One assumption is that a monopoly's supra-competitive pricing attracts entry. ${ }^{211}$ Besides signaling to potential entrants an investment opportunity, exploitive prices can engender consumer outrage, increase scrutiny from lawmakers, and cause adverse reputational effects. In contrast to excessive pricing, the data-opoly, when using the data internally, does not signal to the marketplace its exploitive use of data. ${ }^{212}$ Many consumers do not know all the data being collected about them, the use of the data, and the extent to which they are being exploited as a result of the data collection.

Moreover, data-opolies can persist when their tactics to attain or maintain their dominance avoid antitrust scrutiny. Data-opolies' anticompetitive conduct may be harder to detect, such as their use of the nowcasting radar to squelch nascent competitive threats, their foreclosing of rivals' access to data necessary for them to compete, their leveraging of a data-advantage in one market to gain an advantage in another market, or their increasing customers' switching costs. Moreover, as our book explores, there has been less scrutiny of data-driven mergers by these dominant firms. ${ }^{213}$ Competition authorities' price-centric tools for assessing mergers are often ill-equipped for data-driven mergers, where the service is offered for "free" and advertisers are not harmed. Datadriven mergers (such as if Google or Facebook acquired IAC, which controls the online dating platforms Match, Tinder, PlentyOfFish, and OkCupid) often defy the horizontal, vertical, and conglomerate categories used to assess mergers.

Finally, governmental support of data-opolies might be harder to detect. If a monopoly results from mandatory government standards, trade barriers (a concern during the Sherman Act's enactment), or other governmental intervention (such as granting the company an exclusive franchise or license), this reflects little on the company's skill and more on its political might. For example, high tariffs aided du Pont's dominance of the U.S. cellophane market. ${ }^{214}$ One risk of these governmental protections

211 Matsushita Elec. Indus. Co. v. Zenith Radio Corp., 475 U.S. 574, 589 (1986) ("monopoly pricing may breed quick entry by new competitors eager to share in the excess profits").

212 See generally Frank Pasquale, The Black Box Society: The Secret ALGORITHMS THAT CONTROL MONEY AND INFORMATION (2015).

${ }^{213}$ STUCKE \& GRUNES, supra note 1, at chapters 7-9.

${ }^{214}$ Before 1930 imports were about $20 \%$ of domestic consumption, but there were serious obstacles, including "poorer quality," to successful sale of imported cellophane. In 1929, it was judicially determined, in a suit instituted by du Pont, that cellophane had been given a wrong tariff classification and that the applicable duty was $60 \%$, not $25 \%$, ad 
is their visibility. Citizens, competitors, or the opposing political party may cry foul. Data-opolies can enlist the government, albeit more discreetly.

Consequently, one cannot conclude that data-opolies are ephemeral. Instead, the feedback loop from data-driven network effects can reinforce dominance and prevent rivals, especially those dependent on the data-opoly's platform, from gaining momentum. Data-opolies can use their now-casting radar to squelch any nascent threats. The reality is that data-opolies are not only possible in data-driven markets but in some industries, given the network effects, are very likely.

\section{CONCLUSION}

Several themes run throughout this article. First, the harms from data-opolies can exceed that of earlier monopolies. They can affect not only our wallets but our privacy, autonomy, democracy, and well-being. Second, the data-driven markets dominated by these firms will not necessarily self-correct. Third, antitrust enforcement can play a key role. But antitrust enforcement, while a necessary tool to prevent data-opolies and deter their abuses, is not sufficient. Antitrust enforcers must coordinate with privacy and consumer protection officials to ensure that the conditions for effective privacy competition are in place.

My antitrust professor presciently forewarned, in 1979, how it was "bad history, bad policy, and bad law to exclude certain political values in interpreting the antitrust laws." ${ }^{215}$ Professor Pitofsky raised several concerns: first, "how excessive concentration of economic power will breed antidemocratic political pressures"; second, a "desire to enhance individual and business freedom by reducing the range within which private discretion by a few in the economic sphere controls the welfare of all"; and third, "that if the free-market sector of the economy is allowed to develop under antitrust rules that are blind to all but economic concerns, the likely result will be an economy so dominated by a few corporate

valorem; thereafter imports were negligible. Brief for the United States, United States v. E.I. du Pont de Nemours \& Co., 1955 WL 72626, at *16 (Aug. 5, 1955); see also Wendell Berge, Can We End Monopoly, N.Y. TIMES (Sept. 26, 1943), https://www.nytimes.com/1943/09/26/archives/can-we-end-monopoly-the-chief-of-theantitrust-division-says-we-can.html [https://perma.cc/X548-DVSU] (writing that tariff barriers "culminating in the Hawley-Smoot act, built the final wall behind which American monopolies could dictate their own terms of competition").

${ }^{215}$ Robert Pitofsky, The Political Content of Antitrust, 127 U. PA. L. REV. 1051, 1051 (1979). 
giants that it will be impossible for the state not to play a more intrusive role in economic affairs." 216

The Reagan administration, in espousing the then-popular Chicago School of economics beliefs, discounted these concerns. Now with the rise of a progressive, anti-monopoly New Brandeis School, the pendulum is swinging the other way. ${ }^{217}$ With the emergence of data-opolies, this is a welcome change.

${ }^{216} I d$.

${ }^{217}$ Maurice E. Stucke \& Ariel Ezrachi, The Rise, Fall, and Rebirth of the U.S. Antitrust Movement, HARV. BUS. REV. (Dec. 15, 2017), https://hbr.org/2017/12/the-rise-fall-andrebirth-of-the-u-s-antitrust-movement [https://perma.cc/6A55-MULL]; How Regulators Can Prevent Excessive Concentration Online: Conventional Antitrust Thinking Is Being Disrupted from Within, ECONOMIST (June 28, 2018), https://www.economist.com/special-report/2018/06/28/how-regulators-can-preventexcessive-concentration-online [https://perma.cc/6Q73-YR9H]. 